\title{
Religión popular: fiesta e imagen
}

\author{
FEDERICO AGUIRRE* \\ Pontificia Universidad Católica de Chile (Chile) \\ federico.aguirre@uc.cl
}

\begin{abstract}
Resumen
El presente trabajo busca establecer una base empírica para el estudio de la denominada "religión popular". El objetivo principal de la investigación en la que nuestro estudio se inscribe es desarrollar una reflexión teológico-fundamental sobre dicho fenómeno. Si bien el término en cuestión hace referencia a una instancia muy significativa para la Iglesia de América Latina, dada su generalidad y negatividad ha contribuido a la infravaloración de la realidad a la que hace referencia. En su lugar, planteamos la "fiesta religiosa", en tanto realidad concreta y positiva, como punto de partida para la valoración teológica de los objetos y prácticas que caracterizan la experiencia de fe de los pueblos latinoamericanos. De este modo, proponemos un análisis cualitativo de tres fiestas religiosas que se realizan en Chile, poniendo de relieve el modo "estético" (matérico-sensorial) en que estas se articulan y destacando el rol de "agentes" que asumen las imágenes de culto en este contexto.
\end{abstract}

Palabras clave: Arte, teología, religión popular, fiesta, imagen.

\section{Popular religion: feast and image}

\begin{abstract}
The aim of this article is to establish an empirical basis for the study of the so-called "popular religion". The main goal of the research within the framework of which this work has been elaborated is to develop a theological-fundamental reflection on the above-mentioned phenomenon. Although the term in question refers to a very significant instance for the Latin American Church, it has contributed to the underestimation of the reality to which it refers, due to its general meaning and negative connotations. Instead of this term, we suggest the term "religious feast", in the sense of a concrete and positive reality, as a starting point for the theological evaluation of the objects and practices that characterize the experience of faith of Latin American people. We, thus, propose a qualitative analysis of three religious feasts celebrated in Chile, focusing on the "esthetic" (material-sensory) mode in which they are organized, as well as on the role of "agents" assumed by the cult images in this context.
\end{abstract}

Key words: Art, theology, popular religion, feast, image.

* Doctor en Estudios Culturales y Magister en Teología. Profesor Asistente de la Facultad de Teología e investigador del Centro UC de Estudios de la Religión. Entre sus publicaciones se encuentra el libro Arte y teología. El renacimiento de la pintura de iconos en Grecia moderna (2018). 


\section{INTRODUCCIÓN}

El presente trabajo consiste en el análisis de tres fiestas religiosas que se celebran en Chile. El objetivo principal de este estudio es proveernos de una base empírica para el desarrollo de una reflexión teológico-fundamental sobre la denominada "religión popular", la cual se llevará a cabo en la siguiente etapa del proyecto de investigación que nos encontramos desarrollando ${ }^{1}$. En este sentido, este trabajo contempla una aproximación cualitativa al fenómeno de la fiesta religiosa, sin ser estrictamente un estudio de caso, lo cual requeriría mayor desarrollo en la descripción de cada fiesta del que realizamos aquí.

Así, para los propósitos de nuestra investigación, los casos particulares que presentaremos más adelante tienen como fin aportar una muestra paradigmática del objeto concreto de nuestra reflexión teórica, a saber, la fiesta religiosa ${ }^{2}$.

En el origen de nuestra investigación, justamente, se encuentra la crítica al concepto de "religión popular", el cual posiblemente tenga una cierta funcionalidad en el campo de las ciencias sociales, pero que en el contexto de la reflexión teológica ha conducido recurrentemente a una infravaloración de la realidad eclesial a la que hace referencia (Delgado, 1993) ${ }^{3}$. En este sentido, cabe preguntarse: ¿Por qué en muchos casos se habla de "religiosidad" y no de "religión"? ¿Por qué es necesario añadir el calificativo de "popular"? ¿Tiene un sentido meramente descriptivo (la religiosidad de los sectores populares de la sociedad) o un sentido normativo (la religiosidad no "culta”)? (García, 2003).

1 Este trabajo cuenta con el patrocinio de Fondecyt (Proyecto Fondecyt Iniciación $n^{\circ}$ 11170285, "Fundamentos estético-teológicos de la piedad popular"). Para un resumen del proyecto, véase Aguirre, 2018a.

2 Las fiestas escogidas para nuestro análisis son: 1. La Fiesta de la Virgen de La Tirana; 2. La Fiesta de san Pedro en Valparaíso; 3. La Fiesta del Nazareno de Caguach en Chiloé. La selección se da según los siguientes criterios: a) representatividad geográfico-cultural (norte-cultura andina, centro-cultura criolla, sur-cultura mapuche); b) asociación de cada fiesta a actividades productivas que definen la vida económica del país (minería, pesca y agricultura); c) representatividad devocional del mundo cristiano que ofrecen (Virgen, Santos y Cristo, respectivamente).

3 Para una completa revisión bibliográfica sobre la discusión en torno al tópico "religión popular", con especial énfasis en América Latina y Chile, véase Dawson, 2001. Los conceptos de "catolicismo popular" o "piedad popular" que se divulgan a partir de Evangelii nuntiandi (1975), en nuestra opinión, adolecen de la misma negatividad y ambigüedad. La denominada Teología del Pueblo abre un nuevo horizonte para esta discusión, al plantear la categoría de "pueblo" como hipóstasis cultural de la Iglesia, superando así, en alguna medida, las dicotomías popular-oficial, popular-burgués, popular-culto; véase Gera, 1976. 
Ante la ambigüedad y negatividad intrínseca de dicho término, pues, planteamos la fiesta religiosa como categoría positiva y vinculada a una determinada realidad empírica ${ }^{4}$. Consideramos que en gran medida la inexactitud de la noción de "religión popular", sobre todo aplicado al ámbito de la reflexión teológica, obedece a la indefinición del objeto de estudio y a la incomprensión de los modos en que este se manifiesta.

En el curso de la revisión bibliográfica que antecedió la etapa actual de nuestra investigación, constatamos que se suele señalar como rasgos distintivos de la denominada "religión popular" el carácter marcadamente ritualista de las prácticas que la constituyen y el lenguaje simbólico en el que estas prácticas se comunican y expresan (Parker, 1993; Morandé, 2010) ${ }^{5}$. Así, para la literatura magisterial, prácticas como la veneración de imágenes durante las fiestas religiosas serían "modos directos y simples de manifestar externamente el sentimiento del corazón y el deseo de vivir cristianamente", que habría que "profundizar" para acceder a un contenido determinado, a una "interioridad" más allá de lo sensible, y de este modo evitar "que los gestos simbólicos degeneren en costumbres vacías y, en el peor de los casos, en la superstición" (Congregación para el Culto Divino y la Disciplina de los Sacramentos, 2012: n. 15).

En estas afirmaciones despunta una aventurada dicotomía entre cuerpo y espíritu, subestimándose ciertas prácticas donde el disfrute sensorial juega un rol epistemológico fundamental y malinterpretándose la función litúrgico-sacramental que en dichos contextos cumplen ciertos objetos materiales como son las imágenes. Incluso a partir de otros enfoques, donde el supuesto carácter ritualista y simbólico de las religiones populares es valorado positivamente, se suele reproducir la misma dicotomía entre cuerpo y espíritu, entre lo sensible y lo intelectual, entre lo occidental y lo indígena ${ }^{6}$.

Nuestra hipótesis de trabajo consiste precisamente en plantear aquellos modos "directos" y "simples" de experimentar la fe, aquella "lógica de la vida, la emotividad y el símbolo", como un "lugar teológico" de primer orden para el cristianismo latinoamericano, una "vida teologal" en

\footnotetext{
4 Somos conscientes de que las prácticas y los objetos que caen bajo la denominación de "religión popular" son diversos y no se limitan a los que se observan en las fiestas religiosas. No obstante, en los conceptos "fiesta" e "imagen" reconocemos una dimensión estructural de los modos en que se manifiesta la "religión popular".

5 Respecto a este carácter ritualista y simbólico, de la literatura magisterial véase CELAM, 1968: n. I-4; CELAM, 1979: n. 457 y 465; CELAM, 2007: n. 263; y Congregación para el Culto Divino y la Disciplina de los Sacramentos, 2012: n. 15.

"Es una lógica de la vida, de la emotividad, la simultaneidad, el símbolo y lo sensible frente a la lógica de la razón, la forma, la linealidad, lo sucesivo y lo despersonalizado" (Parker, 1993: 382).
} 
cuyas mismas prácticas y cultura material -y no en un metarrelato teológico- se sustenta su legitimidad, tal como destaca Francisco en Evangelii gaudium (Francisco, 2015: 101-102) 7 . Entendemos los "lugares teológicos" primariamente como aquellas "instancias" de la tradición cristiana que se constituyen en fuente de revelación, donde se da la hermenéutica existencial de la palabra revelada en las Escrituras; prácticas y objetos concretos que se van produciendo en la historia a través de la acción del Espíritu en el corazón de los fieles, ante los cuales la reflexión teológica presenta un carácter derivado (Bentué, 2015: 174-205).

En este sentido, en el marco de nuestra investigación, proponemos que prácticas como la veneración de imágenes en el contexto de las fiestas religiosas que se celebran en Chile encuentran un sólido fundamento dogmático en la denominada "teología de la imagen" desarrollada en torno a la querella iconoclasta ${ }^{8}$. Para trabajar sobre esta hipótesis, y habida cuenta del protagonismo que asume la experiencia sensible, se hace imprescindible describir dichos modos "populares" de experimentar la fe desde su especificidad matérico-sensorial, superando las dicotomías y la indeterminación de los términos empleados hasta ahora para referirse a las prácticas y la cultura material que constituyen la religión popular cristiana.

\section{LA FIESTA RELIGIOSA COMO OBJETO DE ESTUDIO 9}

Detrás de la apreciación dualista de los modos en que la religión popular se expresa y transmite hay dos sesgos, primariamente culturales, que muchas veces operan solapadamente y se revisten de una supuesta legitimidad dogmática, en el caso de la teología, o científica, en el caso de las ciencias sociales ${ }^{10}$.

7 Cabe destacar el vínculo entre los planteamientos de Evangelii gaudium con el enfoque antes mencionado de la Teología del Pueblo (Scanonne, 2014).

8 Para una exposición de estos fundamentos dogmáticos, véase Aguirre, 2018b: 225287. Su vínculo con las fiestas religiosas que presentamos aquí será desarrollado en detalle en la siguiente etapa de nuestra investigación.

9 Respecto al campo de estudio de la fiesta, véase Pieper, 2006; Schultz, 1994. Respecto a la fiesta religiosa, Isambert, 1982. Finalmente, para una mirada local, Plath, 1966; Cruz de Amenábar, 1995; Mercado, 2006.

10 "En efecto, la teoría del animismo es un dispositivo clasificatorio que, como el concepto de ritual, sirve para separar las conductas que entendemos y con las que simpatizamos, de las que nos parecen supersticiosas y perversas." (Gell, 2016: 164). En el ámbito de la reflexión teológica y magisterial católica, en nuestra opinión, eufemismos del tipo "piedad popular" o "catolicismo popular" operan de manera análoga (CELAM, 1979: n. 444-469). Si bien el documento de Aparecida hace una llamada a valorar positivamente lo que el Espíritu ya ha sembrado en las culturas latinoamericanas (CELAM, 2007: n. 262), sigue implícita la asimetría: cuando se trata de una relación 
Por una parte, al menos en América Latina, los medios culturales en los que se ha desarrollado la religión popular han sido sistemáticamente desestimados como subculturas que no han alcanzado un deseable estado de desarrollo, cuyas prácticas religiosas deben ser corregidas. Esta es la perspectiva planteada desde las ciencias sociales por Émile Pin y Françoise Houtart a principios de los años 60, pero que va a tener un impacto importante en el desarrollo de las teologías latinoamericanas (Johansson, 1990: 33-58) ${ }^{11}$.

Por otra parte, y aquí hacemos referencia a una concepción que tiene a lo mucho tres centurias pero que ha marcado el desarrollo de la epistemología moderna, las formas discursivas del arte han sido relegadas a la esfera de lo subjetivo, a una logica facultatis cogoscitivae inferioris, decretando la autonomía de lo sensible ( $\alpha \dot{i} \sigma \theta \dot{\eta} \sigma \iota \varsigma)$ respecto a lo intelegible (voṽ $)$ y, consecuentemente, debilitando el significativo rol epistemológico que el arte siempre ha cumplido $^{12}$.

Para intentar precavernos de estos dos sesgos, el cultural y el epistemológico, hemos optado por desarrollar, en primera instancia, una aproximación empírica a nuestro objeto de estudio, efectuando una suspensión teleológica de la estética y la teología ${ }^{13}$. En ningún caso proponemos una mirada sin sesgos y desprejuiciada, pero al menos sí una mirada consciente de ciertas limitaciones epistemológicas y culturales, que a nuestro parecer

intercultural (interpersonal, en último término) no basta reconocer cierto valor en lo otro, sino que es imprescindible dejarse interpelar por ello.

11 A este respecto, el documento conclusivo de Medellín es bastante explícito: "La religiosidad popular puede ser ocasión o punto de partida para un anuncio de la fe. Sin embargo, se impone una revisión y un estudio científico de la misma, para purificarla de elementos que la hagan inauténtica no destruyendo, sino, por el contrario, valorizando sus elementos positivos" (CELAM, 1968: n. 2). Incluso en el encuentro de Puebla (1979), en torno al que se produce una revaloración de la especificidad cultural latinoamericana, encontramos un tono de sospecha: "la revalorización de la religiosidad popular, a pesar de sus desviaciones y ambigüedades, expresa la identidad religiosa de un pueblo y, al purificarse de eventuales deformaciones, ofrece un lugar privilegiado a la Evangelización" (CELAM, 1979: n. 109).

12 "El propio reparto de la sensibilidad que empezó a institucionalizar la modernidad euroamericana a partir del siglo XVIII se esforzó en unificar una heterogeneidad de prácticas visuales, usos de la obra de arte o modos de recepción en torno a la configuración de una noción categórica de Arte y a la normalización de la experiencia estética.” (Martínez, 2012: 174). Sobre esta crítica a la "estetización” del arte, veáse también Gadamer, 1991: 75120; Gell, 2016: 31-42.

13 Respecto al diseño metodológico de nuestra investigación, véase Aguirre, 2018a: 156-160. 
han obturado el enfoque teológico-fundamental sobre el tema en cuestión ${ }^{14}$. Por lo demás, hay una poderosa razón teológica para realizar esta suspensión teleológica de la teología y enfocar la mirada en las prácticas y las cosas, y es que la Iglesia se caracteriza como una realidad "inculturada", es decir, las culturas (y no solo algunas de ellas) constituyen su condición de posibilidad ${ }^{15}$.

Como hemos indicado, el problema que queremos abordar tiene relación con la aparente incomprensión de la función específica (estético-teológica) que asumen las prácticas y los objetos concretos que dan cuerpo a la religión popular, de modo que el primer paso debe ser elaborar una descripción lo más cuidadosa posible de los mismos. Dicho de otro modo, la cuestión que nos interesa desde un punto de vista teológico-fundamental no es definir qué es la religión popular sino cuál conceptualización se ajusta mejor a una determinada realidad empírica tan relevante para la vida social y eclesial de América Latina (Isambert, 1982: 105).

En efecto, el hecho de comenzar usualmente la reflexión a partir de una definición normativa - como opera, muchas veces, el término "religión popular" - ha contribuido a desenfocar el mismo objeto de estudio, a tal punto que casi cualquier práctica religiosa podría ser considerada como una práctica de religión popular: basta con que presente cierto grado de resistencia respecto a la expresión institucional de las religiones oficiales (sus dogmas, sus monumentos, sus roles), o bien sea entendida como una expresión marginal respecto a la institución, pero que puede ser instrumentalizada por esta. En relación a esto último, en el contexto de la profunda crisis institucional que vive la Iglesia chilena y la sociedad en general, animitas, bailes y Vírgenes andinas han asumido gran protagonismo durante las últimas décadas, incluso en el seno de la institucionalidad cultural y religiosa de nuestro país.

Por otro lado, la mayoría de las veces se desconocen los complejos procesos de institucionalización que existen de facto en aquellas prácticas aparentemente tan espontáneas, como la matriz sindical de los bailes religiosos (Van Kessel, 1987) o las mutuales que han surgido en torno al culto de las animitas (Plath, 2012), procesos que dan lugar a dinámicas propias y que comportan conflictos de poder internos y externos, como toda realidad social mediada por las instituciones.

14 En concreto, nos referimos a los enfoques antes descritos que plantean lo "popular" de manera normativa.

15 "La gracia supone la cultura, y el don de Dios se encarna en la cultura de quien lo recibe" (Francisco, 2015: n. 93). 
¿Por dónde acceder, entonces, a la realidad empírica de la religión popular, habida cuenta de su indefinición o, dicho positivamente, de su heterogeneidad?

Entre las diferentes manifestaciones regularmente catalogadas como expresiones de religión popular, la fiesta religiosa se muestra para nuestro enfoque como un ejemplo paradigmático del objeto de estudio en cuestión, dado que consiste en una expresión concreta de aquellos aspectos generales con los que se suele caracterizar la religión popular, pero a su vez los tensiona: es popular y oficial, civil y religiosa a la vez; se trata, en el fondo, de un sistema de representación volátil, a medio camino entre ortodoxia y heterodoxia social y religiosa (Isambert, 1982: 16) ${ }^{16}$.

En este sentido, la fiesta religiosa, además de tener una evidente dimensión ritual, constituye una forma fundamental de la vida social en nuestro continente (Cruz de Amenábar, 1995: 17-112), llegando a plantearse como una auténtica utopía social - utopía de la vida abundante (Mercado, 2006: 17-28). Así, en cuanto fenómeno socio-cultural, la fiesta religiosa expresa la paradoja esencial de lo que se suele caracterizar como religión popular en América Latina: literalmente rige y organiza el tiempo social - aun cuando este se haya secularizado-, pero a su vez tiene un carácter eminentemente disruptivo y catártico -aun cuando se intente controlar por parte de la autoridad civil y religiosa ${ }^{17}$.

Esta realidad se ve reflejada en la dinámica espacial de la fiesta religiosa, que suele desarrollarse entre un santuario, espacio de control eclesiástico, la plaza, espacio de control civil, y la calle, aquel espacio de desviación que presenta una "permanente tentación de romper con las normas", citando a nuestro filósofo de lo cotidiano (Gianinni, 2004: 38-39). Lo que tiene lugar en este despliegue de la fiesta religiosa es literalmente una lucha —un juegopor el control de lo sagrado, encarnado en una imagen que es raptada momentáneamente de los espacios institucionales por la multitud, para luego ser devuelta a su cela. En esta dinámica de la vida pública, sin embargo, es difícil establecer dónde y por quién se produce el rapto, por la gente en la calle o por la institución religiosa en el santuario, dado que un santuario por definición es una construcción que se erige allí donde se desarrolla una determinada festividad religiosa en torno a un objet trouvé: la imagen de culto.

\footnotetext{
16 La historiadora Isabel Cruz de Amenábar, junto a otros pensadores y pensadoras latinoamericanas, plantea las expresiones contemporáneas de "religiosidad popular" como el vestigio del complejo sistema cultural festivo que configura y caracteriza la vida social en nuestro continente hasta el surgimiento de la República (1995: 66-68).

17 La fiesta "hace confluir en equilibrio lo breve y lo duradero; lo sagrado y lo profano; lo imaginario y lo cotidiano; el juego y la realidad; lo racional y lo intuitivo; lo individual y lo colectivo; la introversión y la extraversión; la autoridad y el vasallaje; el control y la catarsis; la alegría y la tragedia; el arte y la vida." (Cruz de Amenábar, 1995: 13).
} 
Por otro lado, la fiesta en general y la fiesta religiosa en particular son acontecimientos performáticos en sí mismos, es decir, no existen fuera de su representación, lo cual no significa en ningún caso que se trate de un espectáculo sino más bien que constituye un aspecto de la vida ordinaria, su regeneración (Bajtin, 2003) o su metamorfosis (Cruz de Amenábar, 1995). Así, si bien la fiesta es un hecho social, su principio constitutivo es de índole matérico-corporal y, por lo tanto, desborda un análisis puramente semiótico o sociológico, exigiendo una determinada hermenéutica - estética, si se quiere- que "se opone a toda separación de las raíces materiales y corporales del mundo, a todo aislamiento y confinamiento en sí mismo, a todo carácter ideal abstracto o intento de expresión separado e independiente de la tierra y el cuerpo" (Bajtin, 2003: 24).

Este principio matérico-corporal de la fiesta se manifiesta de manera evidente en el caso de las fiestas religiosas que presentaremos más adelante: la fiesta de (la imagen de) la Virgen de La Tirana, la fiesta de (la imagen de) San Pedro de Caleta Portales, y la fiesta de (la imagen de) el Nazareno de Caguach. Como veremos, la estructura de estas fiestas religiosas, es decir, el dónde, el cuándo y el cómo se celebran, se desarrolla en torno a un determinado "objeto" material que polariza todas las acciones que llevan a cabo los "sujetos" celebrantes que asisten a ellas, y al cual los actores de las tres fiestas atribuyen la condición de "persona"18.

\section{LA TEORÍA DE LA AGENCIA}

En las fiestas recién mencionadas, en mayor o menor medida, la fuente del acontecimiento festivo es la misma imagen material: a) cuya ubicación determina el lugar donde se celebra la fiesta, b) cuyo onomástico define la fecha en que esta se celebra, y c) cuya presencia motiva en los asistentes una serie de acciones como engalanar, peregrinar, procesionar, bailar etc., acciones que componen la estructura dramática y ritual de la fiesta y que no tendrían lugar si la imagen no estuviera allí. Así, lo que convoca y origina la fiesta no es una metáfora o una idea simbolizada por la imagen, sino la misma imagen material.

De otro modo, un devoto de la Chinita de La Tirana no renunciaría a su trabajo para asistir a la fiesta, como sucede cada año, o un pescador de la Caleta Portales no se empaparía llevando en anda a San Pedro el día de su

18 "Como materialización de lo sagrado, las imágenes pintadas y esculpidas eran símbolos centrales de las fiestas religiosas [...] Era en la fiesta donde la imagen devota se manifestaba. Cientos o miles de pares de ojos estaban puestos en ella, dando gracias, rogando o implorando; y decenas de manos se acercaban a tocar sus pies, sus reliquias, sus vestidos, para establecer contacto con lo sagrado.” (Cruz de Amenábar, 1995: 68) 
"cumpleaños", como tampoco acudirían miles de personas en pleno invierno a la remota isla de Caguach a visitar al Nazareno, corriendo el riesgo de quedar aislados por las inclemencias del tiempo. No sirve visitar una réplica, esperar a que amaine, o trasladar la imagen a un lugar más asequible: la imagen es la que infunde el espíritu y da vida a la fiesta.

En este sentido, no estamos ante un simple fenómeno de "eficacia simbólica", en el que deben calzar dos estructuras de significado predeterminadas que se encuentran "más allá" de la materialidad de la imagen" ${ }^{19}$. Tampoco se trata de un objeto mágico ante el que han de cumplirse determinados ritos para que se realice un milagro en específico. La imagen, tal como la describen los actores de las tres fiestas que estudiamos, no es un objeto manipulable a discreción al que se le asigna una suerte de correlato simbólico o se le reclama supersticiosamente un poder fabuloso, sino que es una persona que ha de ser conocida y visitada, a la que se le atribuye una determinada agencia, cierto grado de voluntad, intencionalidad y autodeterminación, y con la que se establece una relación personal que involucra a toda una comunidad ${ }^{20}$.

En estos casos, la imagen detenta un tipo de presencia que, como veremos, siempre está asociada a la existencia de un prototipo histórico (Jesucristo, la Virgen, San Pedro), pero que es inseparable de un objeto material concreto, con ciertas características únicas e irrepetibles, con una historia propia vinculada a una comunidad y un territorio, y a la que se le atribuye una alteridad personal determinada por su prototipo, pero a su vez por la interacción con las personas que se relacionan con ella.

No es necesario postular una mentalidad diferente, primitiva o exótica, para explicar qué sucede con las imágenes en estos casos, sino comprender que la atribución de cierta intencionalidad a los objetos constituye una característica del conocimiento humano (Gell, 2016: 167). Como señala Wittgenstein en su temprana crítica a la mirada etnocéntrica de La rama dorada de Frazer:

El disparate consiste, en este caso, en que Frazer lo presenta como si estos pueblos hubieran tenido una idea completamente falsa (incluso demente) del curso de la naturaleza, mientras que ellos solo poseían una interpretación

\footnotetext{
19 "Las teorías semiológicas o interpretativas suponen que las obras de arte son vehículos de un significado - signos, símbolos- que los espectadores tienen que descifrar de acuerdo con el sistema semiológico que utiliza el artista para cifrar su mensaje. No niego que a veces las obras de arte se generan y se reciben como objetos de valoración estética, y que también puedan poseer una función semiótica; lo que rechazo específicamente es la idea de que siempre suceda con ellas." (Gell, 2016: 103)

20 En la presentación de los casos, más adelante, consignamos los testimonios de los actores de las fiestas.
} 
curiosa de los fenómenos. Esto es, su conocimiento de la naturaleza, si lo hubieran puesto por escrito, no se habría diferenciado del nuestro de manera "fundamental". Solo su magia es distinta. (Wittgenstein, 2016: 59)

Sobre el hecho de atribuir intencionalidad a las cosas inanimadas, destaca Alfred Gell, encontramos muchos ejemplos incluso en la cultura occidental, como la molestia que nos provoca un artefacto que no funciona como queremos y que, en muchos casos, nos lleva a increparlo verbalmente o incluso a golpearlo, o la compleja relación que establecen los niños con los muñecos y los adultos con las obras de arte (Gell, 2016: 49). A este respecto, Gell llega a una conclusión análoga a la de Wittgenstein, al plantear que no existe una diferencia fundamental entre el arte "primitivo" y el arte normalizado por la crítica y la teoría estética:

Carece de sentido desarrollar una "teoría del arte" para nuestro arte y otra distinta para el de las culturas que tiempo atrás quedaron bajo el influjo del colonialismo [...] El arte de culturas no occidentales no es en esencia distinto del nuestro, pues lo producen artistas de talento, individuales y creativos, en una expresión espontánea de sus instintos primitivos o también como exponentes comunes de algún estilo "tribal" rígido. (Gell, 2016: 31)

Así, se suele pensar que la admiración y el cuidado de una obra de arte se basaría en una suerte de relación simbólica —no fáctica- con algo que está más allá de la constitución material de dicho objeto (una idea, un valor, una determinada concepción de belleza). Sin embargo, nada tiene de simbólico el hecho de trasladarse miles de kilómetros o pagar grandes sumas de dinero para traer a nuestro país un (una obra de) Van Gogh, un (una obra de) Cézanne, o un (una obra de) Delacroix, y así tener la posibilidad de apreciarlo en vivo y en directo. En la práctica no existe ninguna diferencia entre estas acciones y los sacrificios que realiza un promesante de una fiesta religiosa más que el canon estético — variable según el periodo histórico-, que se pronuncia respecto a la calidad del objeto de dichas acciones, pero que nada dice de las mismas.

Recordemos el revuelo que provocó el robo de El torso de Adele de Auguste Rodin desde el Museo de Bellas Artes en el año 2005 por parte de un estudiante de arte, que proponía la sustracción de la pieza como una manera de hacerla presente. Eventualmente, esta situación hubiera pasado desapercibida como cualquier suceso policial y no habría terminado convirtiéndose en una discusión sobre el sentido del arte de no haber sido por la razón argüida por el joven artista, que justificaba su proceder como una acción de arte o performance. En el documental Robar a Rodin (2017), que enmarca la crónica de este suceso en una sugerente lectura de la cultura 
chilena actual, se narra la auténtica procesión que el estudiante de arte realizó con la pieza de Rodin por las calles de Santiago, para finalmente devolverla. La analogía con la fiesta religiosa es evidente: se sustrae una imagen desde su santuario para luego ser restituida, poniendo de manifiesto la lucha por el control de algo que, en la cultura contemporánea occidental, perfectamente se puede caracterizar como "sagrado" 21 .

Ahora bien, lo que salvó al joven de una eventual pena de cárcel no fue su romántico razonamiento sino sobre todo la calidad de obra de arte de la especie sustraída. Ante el robo de un televisor, por ejemplo, el joven artista no habría corrido la misma suerte frente al poder judicial justificándolo como una acción artística. Es más, lo que salvó a Luis Emilio Onfray no fue su rebuscado argumento "estético", sino sobre todo la agencia social de la misma Adele, que en su calidad de obra de arte otorgó un margen hermenéutico al eventualmente condenable robo del artista.

El concepto de agencia social aplicado a las cosas materiales ha marcado un giro sustancial en la reflexión estética de los últimos treinta años, en concreto a partir de los planteamientos de la denominada new material culture $^{22}$. Este enfoque pone de relieve las limitaciones de la interpretación "estética" de la obra de arte, que distingue taxativamente entre la condición material del símbolo y su estructura de significado, desmaterializando las obras en busca de la propuesta conceptual que estas supuestamente ocultan (Domańska, 2006: 173). El enfoque de la new material culture, en contraste con dicha interpretación, destaca el rol fundamental que juega la materialidad en la configuración del significado de la obra (AA.VV., 1996: 8), poniendo atención al hecho de que las cosas no solo están ahí como objetos, sino que también tienen, en sí mismas y más allá del significado que cada cual les pueda atribuir, un potencial performativo propio y una

21 "Ante todo, no puedo diferenciar entre la exaltación religiosa y la estética; yo diría que los amantes del arte sí adoran las imágenes en los sentidos principales de la palabra, aunque racionalicen su idolatría de facto como un asombro estético. Por tanto, escribir de arte, sea lo que sea, es escribir o de religión, o del sustituto con el que se satisfacen quienes han abandonado las formas públicas de las religiones comunes." (Gell, 2016: 138)

22 Véase AA.VV., 1996; Domańska, 2006; Morgan 2010; Martínez, 2012; y en especial, Gell, 2016: 31-42. Entre otros, se indican los siguientes fenómenos como factores determinantes para este "retorno a las cosas" desarrollado a partir de fines del siglo XX: 1) Crítica al "antropocentrismo" y puesta en valor a otras formas de "existencia" como las plantas, los animales y las cosas; 2) Colapso de los esquemas dicotómicos del tipo espíritumateria, mente-cuerpo, sujeto-objeto; 3) Crisis de identidad respecto a lo que nos constituye como especie y encantamiento por lo "otro"; 4) Crítica a la sociedad de consumo, donde las cosas se valoran exclusivamente en función de su utilidad; 5) Rechazo a enfoques contructivistas y textualistas en vista de recuperar la inmediatez sensorial como modo de relacionarse con la realidad. 
incidencia determinante en la constitución de la trama social (Domańska, 2006: 173$)^{23}$.

Para Alfred Gell, en efecto, las cosas que denominamos "obras de arte" se constituyen en "índices" de la agencia social, es decir, un polo material donde las dinámicas de la vida social se concretizan y se evidencian (Gell, 2016: 94) ${ }^{24}$. Gell toma el término "índice" de la semiótica peirciana, en cuyo contexto es definido como "signo natural", es decir, una entidad que afecta directamente al observador y suscita en él una inferencia causal inmediata respecto a esa entidad o sobre las intenciones de una persona (Peirce, 1986: 45-62) ${ }^{25}$. Como ejemplos de índices en este sentido, Gell menciona el humo que sale por debajo de una puerta, el cual lleva a pensar que hay un incendio; o la sonrisa de una persona desconocida, que se puede interpretar como una señal de amistad. Este tipo de razonamiento "abductivo", que no es demostrable en primer término y que no siempre se corresponde con la realidad, es fundamental para el desarrollo de la vida social y, eventualmente, para no morir consumidos por las llamas de un incendio (Gell, 2016: 44-45) ${ }^{26}$.

De este modo, el estatuto de obra de arte de un determinado objeto no proviene exclusivamente de su naturaleza estética o semiótica, sino más bien del rol que asume ese objeto en el contexto relacional en el que se encuentra, constituyéndose justamente en el índice de una agencia social repartida entre el mismo índice (la obra de arte), el artista (el autor material del índice), el destinatario (o espectador) y el prototipo (la entidad a la que

23 Esta crítica de la new material culture al intelectualismo que caracteriza la concepción moderna de la obra de arte encuentra un eco en la crítica a la conciencia estética desarrollada por la filosofía hermenéutica (Gadamer, 1991: 129-142), la cual es subsidiaria de la distinción de las cosas como un estar-ahí (Vorbandenheit) y un estar-a-la-mano (Zuhandenheit) (Heidegger, 1998: 94-99). "Mi vivir no se me da como un objeto puesto ante mí, ni menos como una forma inmanente a la conciencia, sino como un ocuparse de variadas formas con las cosas, que me involucra y afecta, pues me puede resultar bien o mal." (De la Maza, 2005: 124)

24 Siguiendo la analogía con la filosofía hermenéutica: la obra de arte como "acontecer de la verdad" (Heidegger, 1992).

25 Peirce distingue el "índice" del "ícono" y el "símbolo", los otros dos tipos de signos. El "índice" es un signo relacional que posee un vínculo "existencial" con aquello que representa. No existe en sí mismo, sino en relación a aquello que lo provoca (Peirce pone el ejemplo de una veleta, que se constituye en signo no solo por su forma sino porque el viento la mueve).

26 "Una Abducción es un método para formar una predicción general sin ninguna verdadera seguridad de que tendrá éxito, sea en un caso especial o con carácter general, teniendo como justificación que es la única esperanza posible de regular nuestra conducta futura racionalmente, y que la Inducción, partiendo de experiencias pasadas, nos alienta fuertemente a esperar que tendrá éxito en el futuro." (Peirce, 1986: 40-41) 
el índice hace referencia en virtud de la semejanza, cuya agencia, por ejemplo, en el caso del arte abstracto o el arte decorativo sería eventualmente nula) (Gell, 2016: 43-59). Como subraya Gell, "La agencia no consiste solo en 'elaborar', sino en cualquier modo en que algo afecta a otra cosa" (Gell, 2016: 76), de modo que, en el contexto de esta teoría, para asignar a una cosa o persona el atributo de "agente" da igual lo que estas sean: lo importante es su posición e injerencia en la red de relaciones sociales (Gell, 2016: $167)^{27}$.

Gell ilustra su teoría con una multitud de ejemplos, desde obras de arte renacentistas hasta estatuillas de la Polinesia. En cada caso, los cuatro términos que componen la ecuación de la agencia (índice, artista, destinatario y prototipo) presentan diferentes grados de actividad o pasividad. Por ejemplo, en una determinada obra renacentista, el artista puede tener un rol protagónico en la trama de la agencia, mientras que en el caso de la artesanía o una obra de arte popular dicho protagonismo lo ostenta el destinatario (la tradición) o el prototipo en algunos casos de arte destinado al culto. Lo determinante en la propuesta teórica de Gell, más allá del esquema concreto de la agencia, es que sin el índice esta no se evidencia.

En el caso de las fiestas religiosas que analizaremos, observamos que la imagen opera como índice de la agencia social, dado que se constituye en el nudo visible de la red de relaciones espacio-temporales que configura la fiesta. "No se hace referencia simbólica a tales relaciones como si pudieran existir fuera de su manifestación en esta forma particular, pues ellas han producido esta cosa en su presencia concreta y real" (Gell, 2016: 99). En este sentido, habida cuenta de que la imagen se constituye en el polo del evento festivo, el objeto de nuestro análisis será la relación interpersonal que se establece entre la imagen y los celebrantes, descrita desde su matriz matérico-corporal.

\section{ESTRATEGIA DE ANÁLISIS}

Durante el primer año de nuestra investigación, en colaboración con un equipo interdisciplinar que contó con la participación de teólogos, profesionales de las ciencias sociales y una directora audiovisual, desarrollamos el trabajo de campo que proveyó el material del análisis que presentamos a continuación.

El trabajo de campo se llevó a cabo a través de la denominada "observación participante” (Taylor \& Bogdan, 1987: 31-99), y consistió en

\footnotetext{
$27 \quad$ La diferencia entre la agencia de una persona humana y una cosa sería el carácter "activo" de la primera y el carácter "pasivo" de la segunda. Respecto a la relación entre agencia activa y agencia pasiva, véase Gell, 2016: 69-75.
} 
asistir a las fiestas religiosas y participar en ellas junto con las comunidades celebrantes. Además de la asistencia a las fiestas, se realizaron viajes previos para tomar contacto con informantes claves, y así desarrollar el vínculo con las comunidades. También se realizaron viajes con posterioridad a la fiesta, cuyo objetivo era aportar una retribución a las comunidades que nos acogieron. Esta retribución consistió en presentar y poner a su disposición los documentos audiovisuales que elaboramos para cada fiesta.

Los instrumentos de recolección de la información fueron el registro audiovisual, el cuaderno de campo y la realización de entrevistas en profundidad del tipo historia de vida (Taylor \& Bogdan, 1987: 100-132). Con posterioridad, dicha información fue tabulada en una matriz comparativa de las tres fiestas, en la que se describe, por una parte, la taxonomía de cada fiesta (González, 2017: 12-24) y, por otra, las situaciones concretas de interacción entre las imágenes y los fieles, especificando el tipo de agencia que se desarrolla en torno a la imagen en cada caso.

De este modo, en lo que sigue procederemos a presentar la información recopilada en nuestra matriz, describiendo tres aspectos de cada fiesta: a) Taxonomía de la fiesta, es decir, la información contextual y la estructura interna de la misma (dónde, cuándo y cómo se celebra); b) Tipos de agentes, que consiste en la enumeración de los actores y roles más relevantes para el desarrollo de la fiesta, tanto a un nivel informal como institucional; c) Relación con la imagen, que apunta a describir la relación que establecen los actores de la fiesta (destinatario) con la imagen (en su calidad de índice y prototipo). Finalmente, destinaremos un apartado donde presentaremos de manera comparativa la agencia de la imagen, enfocándonos en aquellas acciones e intenciones que se atribuyen propiamente a la imagen, en su doble condición de índice material y prototipo histórico ${ }^{28}$.

28 Para cada una de las fiestas hemos elaborado un documento audiovisual que complementa la descripción que desarrollamos aquí (en notas subsiguientes señalamos los enlaces correspondientes para su visualización). Nos referiremos al contenido de las entrevistas realizadas en nuestro trabajo de campo con las siguientes abreviaciones:

T1: Bailarín Sioux, mediana edad, antiguo caporal del baile (Fiesta de La Tirana 2018).

T2: Bailarín Sioux, joven adulto, encargado de acompañar la imagen durante el viaje (Fiesta de La Tirana 2018).

T3: Bailarina Sioux, joven adulta, antigua encargada de vestir la imagen (Fiesta de La Tirana 2018).

T4: Bailarina Sioux, mediana edad, presidenta del baile (Fiesta de La Tirana 2018).

SP1: Pescador de la Caleta Portales, mediana edad, dirigente sindical (Fiesta de San Pedro 2018).

SP2: Trabajadora de tierra de la Caleta Portales, mediana edad, miembro de la comisión encargada de engalanar la imagen para la fiesta (Fiesta de San Pedro 2018). 


\section{LA CHINITA DEL TAMARUGAL ${ }^{29}$}

\subsection{Taxonomía de la fiesta}

La fiesta de la Virgen de La Tirana se celebra todos los años entre los días 10 y 19 de julio. El pueblo de La Tirana, sede del Santuario que alberga la imagen de la Virgen del Carmen que se celebra durante la fiesta, se encuentra en la Pampa del Tamarugal, próxima a la ciudad de Iquique, a 84 $\mathrm{km}$ de la misma. A unos $30 \mathrm{~km}$ del Santuario se encuentran las oficinas salitreras de Humberstone y Santa Laura, cuya actividad de extracción minera y el surgimiento del movimiento obrero en nuestro país (que tiene lugar en esta región en los años 30 del siglo XX) fueron determinantes en la definición de la fisonomía actual de la fiesta.

El mito fundacional del Santuario (relacionado con la muerte de la Nusta Huillac, princesa inca que comandaba el último bastión de resistencia indígena del sur andino) se remonta al periodo de la Colonia (Plath, 1966: 145-147). Después de las independencias regionales, el Santuario y sus celebraciones quedaron bajo soberanía del Perú. A finales del siglo XIX, después de la Guerra del Pacífico, dicho territorio fue anexado a Chile, comenzando un intenso proceso de chilenización de la fiesta, que consistió en promover la incipiente cultura pampina que se desarrolla en torno a las salitreras y en marginar los bailes y ritmos andinos, los cuales van a volver a recuperarse a partir del último cuarto del siglo XX. Desde este momento hasta la actualidad, el Norte Grande de Chile va a abrirse cada vez con mayor fuerza al reconocimiento de sus raíces andinas y afrodescendientes $^{30}$.

SP3: Pescador de la Caleta Portales, joven adulto, encargado de pintar la imagen exterior (Fiesta de San Pedro 2018).

C1: Habitante de la isla de Apiao, mediana edad, acordionista (Fiesta de Caguach 2018).

C2: Habitante de la isla de Caguach, joven adulto, participante de la carrera de piraguas, (Fiesta de Caguach 2018).

C3: Habitante de la isla de Caguach, adulto mayor, antiguo Patrón de la fiesta (Fiesta de Caguach 2018).

29 La fiesta de La Tirana es objeto de creciente interés ya desde el siglo pasado, por lo que abundan estudios sobre la misma. Para un informe general sobre la fiesta, remitimos a los ya clásicos volúmenes Núñez, 2015; Van Kessel, 1987; y Uribe, 1976. También remitimos al documento audiovisual que elaboramos con ocasión de esta investigación: F. Aguirre [xamist / art \& theology]. (2 sept. 2019). Feast \& image II: La Chinita de La Tirana [Archivo de video]. Recuperado de https://youtu.be/8NGyZPXWWGw

30 A este respecto cabe destacar el importante desarrollo que ha conocido en las últimas décadas el ya tradicional Carnaval de Arica, espacio de expresión de la heterogénea identidad surandina, llegando a convertirse en el tercer carnaval más 
Es interesante notar que, por una parte, la fiesta de La Tirana asume su forma actual en el periodo de chilenización del Norte Grande (desde finales del siglo XIX hasta mediados del XX), pero que, a su vez, se ha convertido en una de las principales plataformas de reivindicación de aquellas raíces culturales que en aquel periodo fueron revocadas. Así, en la actualidad las Diabladas, los Tinku o los Sambos Caporales (bailes propiamente andinos y afro), con sus coloridos trajes, sus impresionantes coreografías y sus imponentes bandas de bronce eclipsan en alguna medida a los bailes pampinos provenientes de las salitreras (indios Sioux o Pieles Rojas), con una performance menos llamativa y solo con acompañamiento de bombos y cajas.

En general, la fiesta presenta un alto grado de performatividad, que se manifiesta en los bailes que se suceden en todo el pueblo durante día y noche, los trajes, andas y estandartes adornados con multitud de formas, luces y colores, y el tañido incesante de una percusión que, al paso de los días, se termina asentando en los cuerpos de los asistentes. A esta compleja performance en torno a los bailes, habría que añadir el intercambio incesante que se da en las ferias que se instalan en el perímetro del pueblo casi duplicando su extensión, y donde se puede encontrar todo tipo de cosas: batidos de frutas exóticas, tornillos, somvenir religiosos, juegos de realidad virtual, shawarma, aguayos finamente confeccionados, indumentaria militar, etc. Todo este despliegue performático de la fiesta contrasta fuertemente con las precarias edificaciones, el silencio del desierto, su paisaje monocromático, y el contraste de temperaturas que se da entre el día y la noche.

Entre la infinidad de situaciones que se pueden observar durante la fiesta y el ritmo propio de la vida de las sociedades de baile en sus respectivas sedes, despuntan algunos momentos centrales que configuran el arco dramático de la celebración. Entre estos, destacamos los siguientes: i) presentación de los bailes en el Cristo del Calvario (desde el 10 de julio a las 12 am y en los días sucesivos); ii) vigilia de la fiesta (a partir de las $22 \mathrm{hrs}$ del 15 de julio hasta la madrugada del día siguiente); iii) procesión grande (a partir de las 15 hrs del 16 de julio; puede durar entre seis y ocho horas); iv) despedida de los bailes (desde el 17 de julio hasta el 19 de julio). No entraremos en el detalle de estos momentos, dado que nuestro trabajo de campo se focalizó en la relación con la imagen desde la intimidad de la sociedad de baile de los Indios Sioux de Arica, quienes vivieron buena parte de estos momentos en su sede.

importante de América Latina, después del Carnaval de Río de Janeiro y el Carnaval de Oruro. 


\subsection{Tipos de agentes}

Como asistentes y, por tanto, agentes de la fiesta se reconocen cinco grandes grupos con diferentes roles en la articulación de la misma:

Sociedades de baile, se organizan según el modelo sindical con presidente/a, secretario/a y tesorero/a, además de la figura del caporal, quien ejerce una dirección artística y espiritual del baile. Hay sociedades de baile con veinte miembros y otras con doscientos, algunas disponen de una sede bien pertrechada en La Tirana y otras se alojan en campamentos, pero todas comparten la matriz sindical y tienen como núcleo de organización la familia al modo de clanes (Van Kessel, 1987: 232-234). Las sociedades, a su vez, se organizan en asociaciones respondiendo a un patrón metropolitano (Arica, Iquique, Antofagasta, Calama y Tocopilla), todas las cuales constituyen la Federación de bailes religiosos de La Tirana ${ }^{31}$. Cabe señalar que las sociedades de baile, además de bailarines, cuentan con socios, quienes cumplen desde funciones logísticas, muy importantes para la vida del baile y el desarrollo de la fiesta (mantención y limpieza de los espacios, cocina, asistencia a los bailarines, etc.), hasta funciones propiamente rituales como llevar el estandarte, el anda con la imagen, vestir y acicalar la imagen, etc. También hay sociedades que tienen sus propios músicos (como es el caso de los Indios Sioux de Arica), quienes forman parte de la comunidad, mientras que otras los contratan para la fiesta y los ensayos durante el año, trayéndolos a veces de Perú o Bolivia y llegando a pagar grandes sumas de dinero.

Institución eclesiástica, representada durante la fiesta por el obispo de la Diócesis de Iquique y por el rector del Santuario. Ambos tienen un rol protagónico en las celebraciones litúrgicas oficiales durante la fiesta, destacándose en el caso del obispo la celebración de la Eucaristía de las Fuerzas Armadas (14 de julio), la conducción de la vigilia en la plaza (15-16 de julio), y su participación durante la procesión del 16 de julio ${ }^{32}$. En lo que respecta a los bailes de Arica (ciudad a la que pertenece el baile de los

\footnotetext{
31 Nuestro trabajo de campo fue realizado con la Sociedad de baile de los Indios Sioux, perteneciente a la Asociación de San José de Arica, con quienes pasamos toda la fiesta y nos recibieron con gran generosidad.

32 Llama la atención el contraste entre las formas litúrgicas oficiales y la ritualidad propia del baile religioso, que se hace evidente, por ejemplo, en los momentos que desde el templo se pide por altoparlante a los bailes de la plaza que dejen de bailar porque se va a celebrar la Eucaristía. Hay instancias en que se ha buscado incorporar los bailes a la liturgia oficial, como en la misa de la víspera, donde ya es tradicional ver al baile de las Cuyacas esparciendo el incienso en torno al altar. Sin embargo, se hace evidente la existencia de dos estructuras rituales en la fiesta que no han terminado de vincularse armónicamente.
} 
Sioux), la Compañía de Jesús ha realizado una labor notable de acercamiento pastoral desde los años 60 del siglo pasado, testimoniada por los mismos miembros de las sociedades de baile ${ }^{33}$. Cabe recordar que antes de ese periodo, tal como confiesan los mismos miembros de las sociedades de baile de Arica, la actitud de las autoridades eclesiásticas era en muchos casos de censura o de instrumentalización ${ }^{34}$. La clave del éxito de esta vinculación entre los jesuitas y las sociedades de baile ha sido la actitud de escucha y aprendizaje que han asumido los clérigos en este caso, dándose el tiempo de profundizar y conocer la sacramentalidad propia del baile religioso y, desde ahí, construir un puente hacia la sacramentalidad oficial que promueve la institución eclesiástica.

Autoridades civiles y las Fuerzas Armadas ostentan un rol más bien marginal, haciendo literalmente "acto de presencia" en la Eucaristía del 16 de julio. Sí cabe destacar la presencia de Carabineros durante toda la fiesta que, si bien se muestran muy respetuosos con la dinámica festiva de los bailes, asumen una actitud más represiva respecto al comercio informal en colaboración con empleados municipales ${ }^{35}$.

Peregrinos que vienen de todo Chile y el extranjero. Se trata de personas que, sin pertenecer a las sociedades de baile, acuden a la fiesta por una motivación religiosa, asistiendo quizá solo a celebraciones litúrgicas puntuales, pero disfrutando y participando contemplativamente de la performance del baile religioso. Los miembros de las sociedades de baile otorgan el título de "bailarín silencioso" a este perfil de asistente a la fiesta ${ }^{36}$.

Turistas, o personas que visitan la fiesta de manera esporádica y pueden combinar su visita con otras a sitios de interés patrimonial, sin involucrarse particularmente en la ritualidad o los actos institucionales de la fiesta. En este grupo también contamos a los vendedores de las ferias, muchos de ellos provenientes de Perú, Bolivia o migrantes de Colombia, Venezuela y Haiti, quienes cumplen un rol fundamental para el desarrollo de la dimensión socio-económica (mercantil) de la fiesta, pero que no participan en los actos centrales de la misma, dado que no pueden descuidar sus puestos de venta.

\footnotetext{
33 Para una reseña y estudio de la vida de los bailes de Arica y su vínculo con la Compañía de Jesús, véase Peña, 2015.

34 Van Kessel (1987: 232) en su estudio aporta testimonios de los bailarines que se sentían utilizados cuando las autoridades eclesiásticas solicitaban que presentaran sus bailes en eventos públicos, sin comprender que el baile no es un espectáculo sino un acto de veneración dirigido exclusivamente a la persona sagrada de la Virgen.

35 Durante la fiesta no está permitido la venta y el consumo de alcohol.

36 "El danzar solamente no es el revestirse con un traje, el danzar tiene que ser convivir en comunidad con otros que expresan tu misma fe, que expresan tus mismas ganas, que expresan tus mismos sentimientos" (T1).
} 


\subsection{Relación con la imagen}

Durante la fiesta se pueden apreciar infinidad de imágenes, de diferentes estilos y en diversos soportes (desde las efigies del Santuario, hasta la iconografía religiosa que adorna los trajes o las figuras que se venden en la feria). Nosotros nos concentraremos en la imagen de la Virgen del Carmen que llevan a la fiesta los bailes y, en particular, en la imagen del baile de los Indios Sioux de Arica, una figura de yeso de alrededor de un metro y medio, ricamente engalanada y encajada en un anda de base cuadrangular con ruedas, adquirida por el baile hace varias décadas. Cabe destacar, sin embargo, la existencia de dos imágenes "titulares" de la fiesta, es decir, las imágenes-reliquia conservadas en el Santuario (Cruz de Amenábar, 1995: 68). La primera de ellas, la que sale en procesión y preside las celebraciones de la plaza, es una imagen de bastidor del siglo XVIII. La otra, que permanece fija en uno de los altares del transepto y ante la que transitan los peregrinos durante toda la fiesta para establecer un contacto corporal con ella, tiene un aire neoclásico y fue donada por la esposa de un empresario salitrero a principios del siglo XX.

La imagen material de las sociedades de bailes (el "índice”, según la teoría de la agencia), además de ser el foco al que se dirige el acto ritual del baile, preside los espacios donde se desarrolla la vida del baile, tanto durante la fiesta como durante el año ${ }^{37}$. En la fiesta, la imagen se suele ubicar en la cabecera de la sede que, como tipología espacial, se corresponde a un orden basilical (un espacio longitudinal con naves paralelas; en el caso de las sedes de los bailes, la nave central se corresponde con el espacio de convivencia, presidida por la imagen, y las naves laterales con los dormitorios). La imagen en su calidad de índice de la agencia, se ubica en el corazón de la vida del baile, pasa a ser una presencia más, con la que se interactúa en situaciones que adoptan un carácter sacro (vestir la imagen, coronarla, bailar ante ella), y otras que podríamos caracterizar como profanas (comidas, momentos de esparcimiento, elección de presidencia) ${ }^{38}$.

37 "Para mí, esta fe de bailar, como dicen muchos de ellos, es como un rezo. ¿Por qué?, porque tú das tu cansancio. Porque es increíble que acá uno sale con el sol, después sale con todo el frío, y aún así uno está ahí. Entonces, yo creo que la fe se demuestra en eso. Aparte de fe, es gratitud.” (T4). Cabe destacar la dimensión lúdica y de disfrute sensorial que caracteriza el baile, respecto a otras formas de entender la oración como un mero "acto de conciencia".

38 "Para nosotros, la Virgen es todo, el pilar fundamental del baile. Se le dan cuidados pero impresionantes. Ella para nosotros en el bus es un pasajero más. De hecho, yo siempre... Siempre, con los años que llevo, la ponen atrás y cuidado, chalecas para acá, frazadas para que no se doble. A mí este año me tocó irme con la imagen. Lo vi como 
Los miembros de la sociedad de baile llaman cariñosamente a la Virgen la "Chinita". Esta denominación, en terminología de la teoría de la agencia, hace referencia al "prototipo" y es común a todo el norte de Chile. Proviene del quechua y significa "niña", "servidora", "sacerdotisa" 39 . En alguna medida, en dicha denominación se evidencia un imaginario colectivo que vincula a la Virgen María con los pueblos indígenas de la zona, a las funciones sacerdotales que desempeñaba la mujer en el contexto de las religiones prehispánicas, a los cultos a divinidades femeninas como la Pachamama o a la Madre Luna (Quilla), así como a la cotidiana presencia de las madres, que escuchan, acogen e interceden ante la figura lejana y autoritaria del padre ${ }^{40}$.

\section{San Pedro de Caleta Portales ${ }^{41}$}

\subsection{Taxonomía de la fiesta}

La fiesta de san Pedro y san Pablo se celebra el día 29 de junio a lo largo de todo Chile ${ }^{42}$. Es una fiesta especialmente significativa en nuestro país, dado que san Pedro es el patrono de la multitud de pescadores que animan social, económica y culturalmente la larga franja litoral de nuestro territorio. En este sentido, en Valparaíso, dicha fiesta está íntimamente relacionada con su condición de puerto y con la identidad porteña de sus habitantes.

una oportunidad de estar más cerca de ella, estar cuidándola, despertar cada cinco minutos si está bien, no se le corrió ninguna frazada, que no se caiga, no se rompa." (T2). 39 "Las vírgenes escojidas que en el templo del sol tenían a su cargo, entre otros misterios, conservar el fuego sagrado a semejanza de las vestales griegas, llevaban el nombre de chinas (criadas o siervas) de la luz del día. De ahí dimanó que los españoles llamasen al principio chinas a las indias jóvenes y solteras en los conventos de las monjas, después a las indias y mestizas que servían en las casas de familia”. (Meyer, 1952: 37-38)

40 "Yo me recuerdo que en alguna oportunidad le pregunté a mi mamá: -mamá, ¿por qué la Virgen?, y ella me dijo: -la Virgen es la persona que a ti te cuida, que te toma de la mano y que siempre va a estar contigo. Y después le pregunto: - mamá ¿y Dios? - y me dice: Dios es una persona muy grande para nosotros, de la cual no podemos hablar y no podemos preguntarle nada. Era un poco, la concepción de la familia patriarcal" (T1).

41 Para una reseña de la celebración de la fiesta en todo el país, véase Plath, 1966: 128141 y Cruz de Amenábar, 1995: 153-155, y en la zona central de Chile en particular véase Mercado, 2006: 176-179. También remitimos al documento audiovisual que elaboramos con ocasión de esta investigación: F. Aguirre [xamist / art \& theology]. (2 sept. 2019). Feast \& image I: San Pedro de Caleta Portales [Archivo de video]. Recuperado de https://youtu.be/lqiqQXCMCY8

42 "Referencias folclóricas indican que la fiesta de San Pedro ha tenido en Chile dos modalidades principales: una marinera, con procesión, en los puertos, y otra interior con comparsas danzantes y sacrificio de animales.” (Cruz de Amenábar, 1995: 154) 
A diferencia de otras localidades, en Valparaíso la fiesta adopta una traza marcadamente urbana, constituyéndose en una suerte de intervalo en medio del tráfago de la ciudad. Este aspecto es destacable respecto a las otras dos fiestas presentadas aquí, en cuyos casos se trata de Santuarios, espacios sagrados que se activan principalmente durante la fiesta marcando claramente un tiempo de excepción. Por el contrario, la fiesta de san Pedro en Valparaíso se celebra en las mismas caletas, es decir, el lugar donde los pescadores viven gran parte de su cotidianeidad y de su actividad laboral.

Nosotros registramos la celebración que se lleva a cabo en la tradicional Caleta Portales, fundada en 1929 a los pies del Cerro Placeres por los pescadores de la Caleta Jaime, que fueron desplazados en ese momento desde el centro de la ciudad de Valparaíso, donde se asentaron a principios del siglo XIX. De este modo, la fiesta es celebrada por una comunidad que ubica el origen de la misma en el primer tercio del siglo XIX ${ }^{43}$.

Como señalamos más arriba, la fiesta se celebra al interior mismo de la Caleta, que se organiza como un largo corredor junto al mar, donde se guardan las embarcaciones y se venden durante la mañana los frutos del mar extraídos en la madrugada. Por el lado oriente, este espacio se encuentra flanqueado por una construcción longitudinal donde se ubican bodegas y la sede del Sindicato de pescadores.

Uno de los actos centrales de la fiesta de san Pedro en las costas chilenas es la procesión por mar, llevando la imagen del santo a diferentes puntos de la bahía en las embarcaciones adornadas como auténticas andas. En el año 2018, cuando asistimos a la fiesta, la procesión marítima no se pudo llevar a cabo a causa de las condiciones climáticas, por lo que se realizó por tierra el día domingo primero de julio desde la Parroquia de Lourdes, ubicada en lo alto del Cerro Placeres, hasta la Caleta.

En torno a este acto central de la fiesta, que marca el clímax de la misma, se identifican los siguientes momentos: i) la celebración de una Eucaristía presidida por el párroco de la Parroquia de Lourdes el día viernes 29 de junio por la tarde, dando inicio a las celebraciones; ii) el mismo día por la noche se organizó un fogón en la Caleta y se presentaron agrupaciones de bailes que fueron admiradas por los miembros de la Caleta; iii) durante el sábado 30 de junio se realizaron los preparativos para la procesión, y al atardecer de ese mismo día la imagen de San Pedro fue llevada desde la Caleta hasta la Parroquia de Lourdes en el Cerro Placeres, donde pasó la noche; iv) luego de la procesión, que comenzó a las 10 de la mañana del 1 de julio con una misa en la Parroquia, se celebró un almuerzo

43 La fiesta en cuestión data de época colonial, pero fue proscrita durante un periodo a principios del siglo XIX por ser considerada pagana (Plath, 1966: 128). 
en la Caleta, al que asistieron, además de sus miembros, representantes políticos de la región y autoridades militares.

Cabe destacar el carácter más bien cívico que asume la fiesta en este caso en particular. En este sentido, la imagen de San Pedro no detenta el protagonismo que tiene la imagen en las otras fiestas estudiadas o, más bien, se convierte en la depositaria de una identidad colectiva que es propiamente el objeto de la fiesta. Lo que se celebra es la vida del pescador y todas las vicisitudes que conlleva, realizándose a su vez, en la ocasión en que realizamos nuestro trabajo de campo, una fuerte reivindicación política respecto a la Ley de Pesca que tanto ha perjudicado a la pesca artesanal de nuestro país (véase el documento audiovidual reseñado más arriba).

Este carácter cívico de la fiesta también se evidencia en la naturaleza más bien folclórica de los bailes que la animan: asociaciones de Tinkus y Sambos Caporales que no bailan a la imagen sino para los asistentes, a diferencia de los bailes de La Tirana, por ejemplo ${ }^{44}$. A su vez, se hace más patente la desconexión con la Iglesia institucional, por la baja participación en las dos celebraciones eucarísticas y la descoordinación que pudimos observar en el templo cuando los pescadores llegan con la imagen a la Parroquia de Lourdes.

\subsection{Tipos de agentes}

El principal agente del evento festivo en este caso es el Sindicato de pescadores. Sus miembros son los encargados de organizar y financiar la fiesta, así como de definir la estructura que esta tendrá. Así, hay un comisionado general (el presidente del sindicato), un encargado del presupuesto, y un delegado para las actividades culturales que animan la fiesta. El sindicato está compuesto por los pescadores y los trabajadores de tierra (estos últimos, principalmente mujeres y jóvenes). Como destacan los informantes, la vida del pescador es una vida sacrificada, a merced de las inclemencias del tiempo, pero a su vez una vida de aventura que atrae y contrasta con la monotonía de otras ocupaciones. Por su parte, las y los trabajadores de tierra, apoyan en todas las tareas de preparación para la pesca: reparación de las redes, colocación de carnadas, limpieza de utensi-

\footnotetext{
44 Hasta hace unos años, relatan los miembros de la Caleta, asistían bailes chinos de la zona central de Chile, los cuales habrían dejado de acudir a causa de esta folclorización de los bailes. "Un ritual de bailes de chinos es una fiesta que organiza una determinada comunidad, pueblo o caleta para celebrar a un Santo Patrono, a la Virgen, al Niño Dios o alguna fecha importante del calendario católico. El pueblo que celebrará la fiesta invita a grupos de bailes de otros pueblos y todos se juntan el día determinado a tocar y danzar en honor de la imagen venerada." (Mercado, 2006: 61)
} 
lios, venta de los productos extraídos, etc. Si bien en su mayoría son mujeres (madres, esposas e hijas de los pescadores), también existen mujeres pescadoras que salen a la mar. A su vez, los jóvenes aspirantes a pescadores, a modo de iniciación, deben pasar un tiempo trabajando en tierra antes de hacerse a la mar.

La presencia de la Institución eclesiástica es más bien marginal, manifestándose solo a través de la celebración de dos Eucaristías de baja participación. Si bien en un momento la imagen es llevada a la Parroquia de Lourdes del Cerro Placeres —es depositada momentáneamente en espacio sagrado- el día anterior a la procesión, las autoridades eclesiásticas no participan mayormente de la fiesta. Según el testimonio de los informantes, en el pasado existió una pastoral que daba continuidad y vida al vínculo con la parroquia.

Las Autoridades civiles y fuerzas armadas que asistieron al almuerzo del día 1 de julio tampoco ostentan mayor participación. Durante el almuerzo, se vinculan principalmente con la dirigencia del Sindicato, aprovechándose también como una instancia de lobby político.

Junto con los pescadores agrupados en el Sindicato, las Agrupaciones culturales que asisten a la fiesta juegan un rol crucial en el desarrollo de la misma. Se trata de grupos de bailes folclóricos de la ciudad de Valparaíso, algunos de ellos vinculados a agrupaciones de Bolivia (como el caso de los Tinku y los Sambos Caporales que mencionamos más arriba). Como ya señalamos, los bailes asumen más bien un rol de animación, convirtiéndose en una exhibición artística en lugar de un acto ritual de veneración a la imagen. A su vez, cabe destacar la participación de la banda de bronces San Pedro de Valparaíso, la cual también anima el evento festivo y tiene una relación estrecha con los miembros de la Caleta. En este sentido, la fiesta de San Pedro se convierte en una escena especial para la actuación de la banda, espacio en el que reivindica su identidad popular y su compromiso con las demandas políticas de los pescadores.

Finalmente, cabe mencionar la presencia de algunos Turistas que pueden haber tenido noticia de la realización de la fiesta o bien acudieron a la Caleta en el momento en que esta se celebraba. Se trata principalmente de vecinos de la zona o algún turista extranjero que se bajó desprevenidamente en la parada del tren urbano, pero en cualquier caso son actores que pasan más bien desapercibidos frente al conjunto de los miembros de la Caleta y que probablemente dan un paseo y se van, sin participar de actividades principales como la procesión o el almuerzo del día 1 de julio. 


\subsection{Relación con la imagen}

Los miembros de la Caleta poseen dos imágenes de yeso de San Pedro, una estatua de tamaño natural fijada en un pedestal al exterior, junto a la entrada de la sede sindical, y otra imagen pequeña de alrededor de un metro de altura adherida a un anda de madera con forma de barca, que conservan al interior de la sede. La primera imagen permanece fija y ante ella se desarrollan las actividades recreativas de la fiesta (bailes y música); la segunda es la que sale en procesión, y durante el año se conserva al interior de la sede.

En su calidad de indice, la imagen principal de la fiesta es la más pequeña, pues en virtud de su movilidad es la que sale en procesión después de haber sido adornada cuidadosamente ${ }^{45}$. Sin embargo, la imagen exterior es la que anima la devoción cotidiana, expresada en reverencias, saludos, miradas y oraciones que se dirigen cada día a esta imagen, para encomendar la salida a la mar y para agradecer el regreso sin novedades. Así, esta última imagen también es engalanada y "vestida" para la fiesta ${ }^{46}$.

Como destacan los informantes, todos los pescadores se encomiendan a San Pedro: creyentes, no creyentes, e incluso miembros de Iglesias evangélicas. En cuanto prototipo, reconocen en San Pedro a aquel discípulo analfabeto de Jesucristo que fue tozudamente fiel, a pesar de su traición ${ }^{47}$. Además de la advocación tradicional del Santo como patrono de los pescadores, se reconoce a San Pedro como alguien familiar, reivindicando una relación de parentesco con un santo cercano, casi profano, que conoce de cerca las penas y alegrías que ellos experimentan, que conoce la debilidad humana, pero que posee el temple necesario para afrontar la adversidad.

45 “Adornar a San Pedro. Lo pusimos... ¡Lo pusimos hermoso! Le sacamos todo lo viejo que tenía y le pusimos todo lo nuevo que compramos la Comisión de San Pedro. Porque lo lavamos, adornamos el bote, le pusimos flores, lo tratamos de dejar lo más bonito que sea, para que se vea bonito. Ya para que mañana... Esté algo lindo, y podamos salir a la mar también, porque esto no es solamente acá, como se dice, en tierra, porque los botes salen a la mar cuando está la mar buena, o no hay mal tiempo, lo veneran en la mar." (SP2).

46 Ambas imágenes están pintadas, a diferencia de las de bastidor que tienen vestidos de tela. Sin embargo, como declara un informante, “Todos los años «se le cambia ropa», como se dice. No se pinta, se le cambia ropa." (SP3).

47 "Era un poquito como... Como eran nuestros antepasados, un poquito bruto. Nosotros nos identificamos con San Pedro porque somos descendientes de él. ¿Por qué? Porque, ¿por qué lo eligió Dios? Por su fe. Porque nosotros nos vamos a la faena de pesca con toda la fe. Y a veces regresamos sin nada. Al otro día, nos levantamos otra vez con más fe, para hacer nuestro trabajo. Y para llevar el sustento a los hogares.” (SP1) 


\section{El divino Jesús NAZARENO DE CAGUACH ${ }^{48}$}

\subsection{Taxonomía de la fiesta}

La fiesta del divino Jesús Nazareno de Caguach se celebra todos los años entre los días 21 y 31 de agosto en la isla de Caguach, que cuenta con una población de alrededor de quinientos habitantes. Se realiza desde hace casi doscientos cincuenta años de manera ininterrumpida, y reúne a los habitantes de cinco islas del archipiélago de Quinchao: Caguach, Apiao, Tac, Alao y Chaulinec ${ }^{49}$. De las tres fiestas estudiadas, quizá en este caso es donde queda más de manifiesto el carácter de índice de agencia social (y política) de la imagen, pues los habitantes de las islas identifican el origen de la celebración con la llegada de la imagen a Caguach, reconociendo en ella un factor de cohesión social y de identidad religiosa: sin ella no se hubiera producido la paz entre los cinco pueblos y sin ella no hubiera llegado la religión, según indican los informantes ${ }^{50}$.

La leyenda dice que Fray Hilario Martínez, franciscano español asentado en Tenaún (isla grande de Chiloé), ofreció a los caciques de las cinco islas la imagen, a causa de una afrenta que habría sufrido él por parte de los habitantes de Tenaún, quienes ya no merecían conservarla (Cárdenas \& Trujillo, 1986: 21-25). Para resolver quién custodiaría la imagen, se realizó una carrera de piraguas entre las cinco islas mencionadas más arriba, en la que resultaron victoriosos los habitantes de Caguach, significando este hecho, además de la adjudicación de la imagen, la celebración del vínculo fraternal entre las cinco islas, quienes son propiamente los poseedores de la imagen ${ }^{51}$. Este relato habría que contextualizarlo en la co-

48 Existe abundante bibliografía respecto a los tesoros patrimoniales de Chiloé. Remitimos aquí a dos estudios sobre la fiesta de Caguach en particular: Cárdenas \& Trujillo, 1986; Moulián, 2011. También remitimos al documento audiovisual que elaboramos con ocasión de esta investigación: F. Aguirre [xamist / art \& theology]. (2 sept. 2019). Feast \& image III: El divino Nazareno de Caguach [Archivo de video]. Recuperado de https://youtu.be/iPkfXx9utXE

49 Desde el bicentenario de la fiesta, hace cuarenta años, se viene celebrando también en enero, cuando las condiciones climáticas son más favorables, pero asume un carácter más turístico.

50 "Porque hubo un conflicto antes. Es que dicen que antes no había paz, se llevaban peleando por las islas hermanas. Entonces, cuando vino el Nazareno, él vino a poner la paz, y eso que se hace un batido de banderas acá, la procesión de banderas que le llamamos, ese es un signo de paz que hacen los que somos de las cinco islas." (C1).

51 Cabe destacar que, durante nuestro trabajo de campo, los habitantes de Caguach siempre fueron muy cuidadosos en indicar que la fiesta y la imagen pertenecen a las cinco 
nocida estrategia de evangelización a través de las imágenes, que se consolida después del Concilio de Trento y que selló la propagación del cristianismo en América Latina. También hay que señalar que existe un inventario datado en 1778, año en que la imagen llega a Caguach, donde se consigna que la adquisición de esta fue fruto de un intercambio comercial entre el fraile franciscano y los caciques de las cinco islas (Cárdenas \& Trujillo, 1986: 26; Moulián, 2011: 111).

El principal espacio de celebración de la fiesta es una amplia explanada de pasto de unos doscientos cincuenta metros de largo por unos ochenta metros de ancho, situada al frente de la fachada de la Iglesia, flanqueada por casas en ambos lados. En el lado poniente, casi a dos tercios de su extensión, las casas son reemplazadas por un pequeño bosque que la separa de la playa. En la explanada tiene lugar la llamada procesión de banderas el día 29 de agosto, acto que celebra la hermandad de las cinco islas; allí también se realiza la procesión principal con la imagen del Nazareno escoltada por la comitiva de imágenes que han llegado desde las otras islas, el día 30 de agosto (jornada que concentra los actos litúrgicos centrales); y finalmente, en dicho espacio se despliegan los bailes y comidas que animan la fiesta del Cabildo, que tiene lugar el 31 de agosto. También este espacio central es animado esporádicamente por el trajín de los preparativos y de la llegada ocasional de los habitantes de las cinco islas, que desembarcan en el muelle ubicado a unos pocos metros por el lado poniente, para luego atravesar la explanada en dirección al templo.

A diferencia de la fiesta de La Tirana, donde se da una saturación sensorial ininterrumpida, los diez días de la fiesta transcurren en Caguach en medio de la reserva impuesta por el viento y la lluvia, que lleva a los lugareños a retirarse a sus casas y a los visitantes de las otras islas a guarecerse en unos precarios refugios ubicados junto al bosque de la explanada. Esta suerte de saturación negativa contrasta con momentos como la procesión principal, para la que suele tocar buen tiempo, o con la "preba", la carrera de botes a remo que se realiza el 25 de agosto entre las cinco islas para conmemorar el evento fundacional de la fiesta ${ }^{52}$.

Además de la explanada, la misma Iglesia, con su tradicional arquitectura basada en la ingeniería náutica de la zona, se constituye en un espacio crucial para el desarrollo de la fiesta. En este lugar se desarrolla la novena que da inicio a las celebraciones el día 21 de agosto, a la que acuden cada

islas, por lo que ellos no podían hablar por todos, manifestando un auténtico espíritu de sinodalidad.

52 "El remero se entrega... Ese esfuerzo que hace lo entrega al Cristo Nazareno, a la imagen. $\mathrm{Y}$ es algo que te marca a ti para siempre. Era tanta la adrenalina que tu cuerpo pasa a otro nivel." (C2). 
día un número reducido de personas, así como la procesión del Santísimo, que se realiza el 28 de agosto, también con una concurrencia menor que los actos más masivos de la fiesta: la "preba", la procesión de banderas y la procesión con la imagen. El interior de la Iglesia también acoge la permanente circulación de los fieles que van llegando para encender velas y que buscan - sobre todo aquellos que vienen de otras islas o del continente- un momento de intimidad con el Nazareno. En este sentido, adopta especial relevancia el momento en que la talla barroca se traslada desde el altar mayor hacia la balaustrada que separa el altar de la asamblea.

\subsection{Tipos de agentes}

El Cabildo constituye la unidad básica de organización social de las islas que participan de la fiesta. Esta institución, constituida durante la Colonia, tuvo un rol fundamental en el sistema festivo latinoamericano, y ante la ausencia de institucionalidad política y religiosa que caracteriza la vida de las islas (en Caguach no hay siquiera un retén de Carabineros), ejerce en la práctica como asamblea local para la toma de decisiones ${ }^{53}$. En efecto, a mediados de julio se inician los preparativos de la fiesta con la elección de cargos del Cabildo, transformándose en una instancia fundamental para el desarrollo de la misma cada año (Moulián, 2011: 112).

Uno de los cargos más importantes es el Patrón de las imágenes. Se trata de la persona que queda a cargo de una imagen por un periodo de tiempo determinado, debiendo encargarse de cuidarla y engalanarla durante todo el año y con especial esmero durante el desarrollo de la fiesta. El Patrón de la imagen del Nazareno, además, está encargado de dirigir los momentos más importantes de la fiesta, como la procesión de banderas, en la que lidera la coreografía donde participan habitantes de las cinco islas, o la procesión principal del día 30 de agosto. También asume un liderazgo en la comunidad durante todo el año, convirtiéndose muchas veces en garante de la paz o en fuente de conflicto ${ }^{54}$.

\footnotetext{
53 "Estas corporaciones no solo tomaron parte activa en la gran mayoría de las fiestas religiosas comunes a todo el mundo católico, sino además organizaron y financiaron aquellas festividades instituidas en cada ciudad con motivo de una especial devoción o de una finalidad determinada" (Cruz de Amenábar, 1995: 39).

54 Cabe destacar que durante nuestro trabajo de campo se hizo manifiesta la tensión política que conlleva este cargo, pues había asumido un rol mediador entre la autoridad eclesiástica (prácticamente ausente durante el año pero que reivindica el protagonismo durante la celebración de la fiesta) y la comunidad de base que en muchas ocasiones se ve pasada a llevar y desconoce los acuerdos entre el Patrón y el rector del Santuario. El conflicto se origina con la suspensión de la denominada Comisión de Iglesia, entidad constituida cada año por la comunidad de Caguach para la organización de la logística de
} 
El Fiscal, tradicional institución laical del archipiélago de Chiloé, en alguna medida pasa a un segundo plano respecto al liderazgo que asume el Patrón. Recordemos que durante la Colonia se instituyó este cargo en el contexto de las denominadas "misiones circulares" de los Jesuitas que, a causa de lo esporádico de sus visitas, nombraban a miembros seglares de las comunidades - indígenas e incluso mujeres- para que lideraran el incipiente proceso de evangelización iniciado por los sacerdotes españoles. Esta estrategia pastoral, además de tener un fin práctico, es un precedente importantísimo y un modelo de inculturación en el que los mismos miembros de las comunidades se convierten en agentes de su evangelización. Una de las tareas del Fiscal durante la fiesta es la conducción de la Novena.

Como ya hemos señalado, la presencia de la Institución eclesiástica, representada principalmente por el rector del Santuario y el obispo de Ancud, no ha estado exenta de conflictividad durante los últimos años. A diferencia del caso de La Tirana, donde en la actualidad se da durante todo el año un trabajo colaborativo entre sacerdotes y sociedades de baile, o el caso de la Fiesta de San Pedro, donde la institución religiosa casi no interviene en la organización de la misma, en Caguach se da una tensión marcada por la injerencia que reclaman las autoridades eclesiásticas en la vida de una comunidad con la que prácticamente no se relacionan durante el año ${ }^{55}$. Sin embargo, en contraste con la situación actual, las comunidades de las islas recuerdan con especial aprecio la figura del obispo Juan Luis Ysern y la cercanía del sacerdote Mariano Puga.

Autoridades civiles y fuerzas armadas, al igual que en todas las fiestas estudiadas, a Caguach arriban el día de la fiesta las autoridades civiles y militares, especialmente de la Armada de Chile. Sin embargo, su presencia contrasta más en el caso de una isla que no cuenta con nada más que un consultorio de CESFAM. Digna de mencionar es la tradicional visita de la familia Kochifas, dueña de la flota de cruceros Skorpios de Puerto Montt, que cada año arriba a la isla el día de la procesión principal llevando a benefactores de todo el mundo que hacen una solemne entrega de regalos a los niños en la Escuela de la isla.

la fiesta. Originalmente, esta era la instancia mediadora entre la institucionalidad eclesiástica y los habitantes de las islas, sobre todo en lo relativo a la administración de los recursos económicos (Moulián, 2011: 115). Después de un enconado conflicto entre el actual obispo de Ancud y la comunidad de las islas, que tuvo lugar el año 2019 y que fue cubierto por diversos medios de prensa, finalmente se terminó restituyendo la Comisión de Iglesia.

55 Un episodio especialmente doloroso, sobre todo tomando en cuenta el significado de la imagen para la comunidad, fue la decisión arbitraria del obispo actual de sacar en procesión hace algunos años al Nazareno vestido de blanco, cuando su traje tradicional es de color morado. 
Durante nuestro trabajo de campo, llamó la atención la presencia de observadores etnográficos, que sobresalían con sus aparatos de registro en medio de la calma de la isla, y en muchos casos intervenían imprudentemente en el desarrollo de la fiesta ${ }^{56}$. La misma comunidad de las islas expresaba cierta molestia y desconfianza respecto a estas visitas, dado que rara vez los retribuyen, aunque sea con una muestra de sus registros.

Dada las dificultades de acceso durante la época en que se celebra la fiesta, no se aprecia mucha presencia de turistas. Lo que sí llama la atención es la masiva llegada de Peregrinos provenientes de todo Chile el día de la procesión, principalmente de la zona sur. Entre ellos destacan los que llegan de la zona de Calbuco y la región de Aysén, donde trabajan muchos habitantes de las islas, así como de la ciudad de Punta Arenas, que acoge la mayor diáspora histórica de chilotes en el sur. Cientos de personas llegan a cumplir sus mandas y encender una vela al Nazareno, en lugar de las pródigas ofrendas en especies que se permitían antiguamente.

\subsection{Relación con la imagen}

La imagen del Nazareno, el poderoso, es una talla barroca de madera de más de dos metros de alto que representa a Jesucristo cargando la Cruz. Ostenta una corona de plata de tres potencias, y de su rostro policromado con una carnación de colores fríos despuntan vivaces ojos de cristal, sobre los cuales a su vez cae una cabellera de pelo natural. Los pobladores de las cinco islas y los peregrinos acuden fielmente cada año a visitar la imagen y se llevan un trozo de su vestido, pero para los habitantes de Caguach el "santinto" está siempre ahí, como dueño y señor del templo, constituyéndose en el indice central no solo de la fiesta sino de la vida cotidiana de la isla, de manera análoga a lo que sucede con la imagen exterior de San Pedro en Caleta Portales.

En este sentido, no llama la atención que toda la vida religiosa de la isla se vincule más bien periféricamente con la institucionalidad católica y se condense en esta figura barroca, casi de carne y hueso, que jamás los ha abandonado $^{57}$. Junto a ella, en el ábside del templo, los fieles se han apro-

\footnotetext{
56 Rodrigo Moulián (2011: 108) en su estudio también destaca este perfil de asistentes a la fiesta, junto con el de comerciantes; estos últimos, en el periodo de nuestro trabajo de campo, no tuvieron mayor protagonismo, pues por lo que comentaban los habitantes de las islas se ha restringido bastante el comercio informal, limitándose casi exclusivamente a la oferta de comidas de los mismos habitantes de Caguach.

57 "Es más que creer en el amigo sacerdote, va más allá de eso. No es solamente irse a sentar a una misa y escuchar lo que dice el sacerdote, tú al sacerdote lo ves para las misas y para de contar, porque después el resto del año tú te las arreglas solo y es solamente el
} 
piado del lugar más sagrado, el altar, en torno al que van disponiendo libremente todo tipo de exvotos y recuerdos en la misma lógica espontánea de las animitas, sorteando, gracias al aislamiento, la censura que se puede observar en otros templos de Chiloé por parte de los entes estatales de administración patrimonial, que acordonan los altares para evitar el contacto con las imágenes y de ese modo "preservarlas".

Cabe señalar la presencia de otras imágenes propias de Caguach y las que vienen de las otras islas, como la hermosa Virgen de Tac, que visitan al Nazareno y lo acompañan en la procesión principal. En su calidad de prototipo, el Nazareno se identifica con la figura del Cristo vivo que bajó del cielo para caminar junto a su pueblo, el Hijo de Dios hecho hombre ${ }^{58}$. Como complemento de esta dimensión divina, para las generaciones más jóvenes el Nazareno es un modelo de liderazgo que no se corrompe y que pervive hasta la actualidad, convirtiéndose en un referente concreto y cercano para sus vidas ${ }^{59}$. En este sentido, también habría que destacar la instancia de la fiesta como un espacio de reivindicación de la identidad indígena de los habitantes de las islas, que se ha ido reforzando en los últimos años y respecto a lo cual durante el periodo de nuestro trabajo de campo se produjo un importante precedente, al emplear por primera vez la bandera huilliche como emblema de una de las chalupas que representó a Caguach durante la "preba"

\section{LA IMAGEN COMO AGENTE}

Como hemos visto hasta aquí, en cada uno de los casos analizados la fiesta religiosa se convierte en un catalizador fundamental de la vida social, llegando a convertirse, en muchas ocasiones, en el único espacio formal de participación ciudadana para sectores históricamente marginados de la

\footnotetext{
Nazareno el que tienes ahí, cuando a ti te va bien o te va mal, solo él, es él no más el que está ahî" (C2).

58 "En la procesión general salen todas las imágenes... acompañado, como que fuera... un Cristo predicador, y nosotros los moradores, su gente, lo anda siguiendo todos atrás." (C1). "Porque más allá de que existan muchos santos, cierto, Jesús y Cristo fue uno solo. Y más allá de que muchos a veces nos aferremos a otros, es él no más, Dios hecho hombre." (C2).

59 "Lograr unir a tanta gente, con ideas, con principios, es como eso. Ese liderazgo que llegó a tener, que hasta los días de hoy pocas personas han tenido, o sea yo creo que nadie ha tenido esa capacidad de unir a tanta gente [...] Porque a veces tenemos líderes, cierto, que de un día para otro nos damos cuenta que simplemente han sido líderes que nos han engañado, que no.... los líderes típicos terrenales, pero, él no”. (C2).

60 "Si me dan la posibilidad de usar esa bandera, yo voy a hacer un recordatorio como un homenaje a los primeros ancestros que tuvieron... Que empezaron la festividad, que fueron los huilliches y tenían su bandera." (C3).
} 
sociedad ${ }^{61}$. En este sentido, cada fiesta estudiada es ocasión de una reivindicación política: la naturaleza sindical del baile, la restitución de la pesca artesanal, la defensa de la identidad indígena. También hemos visto que la dimensión religiosa de la fiesta adopta diferentes modos de celebración - carnavalesca, quizá, en Tirana, más cívica en Caleta Portales, y con un talante más introspectivo en Caguach. En todos los casos, sin embargo, la imagen concreta que se celebra, desde su especificidad material, es el "objeto" principal de una serie de prácticas que dan cuerpo a los actos de los "sujetos" celebrantes.

Ahora bien, como adelantamos en la segunda parte de nuestro estudio al referirnos a la teoría de la agencia, la imagen no se limita a su condición de objeto material manipulado por sujetos humanos, sino que ella también es protagonista de acciones, convirtiéndose en un actor más de la fiesta al manifestar voluntad ${ }^{62}$. La imagen detenta ciertos idearios que mueven a la reivindicación y posee una naturaleza sagrada que impele a realizar ejercicios corporales que expresan agradecimiento y sacrificio, como el bailar o el remar (agencia externa). Sin embargo, la imagen también hace cosas por sí misma (agencia interna): en Caguach el Nazareno cambia el aspecto de su rostro vaticinando que algo sucederá; en Tirana la Chinita expresa su disconformidad respecto al modo en que es acicalada; incluso el San Pedro de los pescadores, cuya efigie pasa a un segundo plano en el marco de una celebración de carácter más recreativo, para esta ocasión no se le pinta, como si fuera un objeto manipulable a discreción, sino que se le "viste" y se le saluda respetuosamente en el día a día de la Caleta.

Un observador desapercibido o incapaz de suspender ciertos prejuicios y conceptualizaciones podrá identificar en estas situaciones solo la superstición del pueblo inculto, que no es capaz de darse cuenta de que los objetos inanimados no hacen cosas. Sin embargo, las personas que atribuyen estas acciones a la imagen tienen muy clara la distinción entre indice (la cosa material) y prototipo (la persona histórica que la imagen representa $)^{63}$. En todos los casos, los celebrantes tienen plena conciencia de que

61 Parker (1993) destacará esta dimensión de las "religiones populares" al hablar de estas como espacios de "resistencia simbólica".

62 Recordemos que para atribuir agencia a una persona u objeto lo determinante no es su "naturaleza", inanimada o animada, sino su incidencia en la dinámica social. Alfred Gell habla de agencia en términos del hacer cosas con la imagen (agencia externa) y de las cosas que hace la imagen (agencia interna); aún cuando la imagen es un objeto inerte, se le atribuye un actuar intencional, como si en ella operara algo así como un alma (Gell, 2016: 170-178).

63 "La pregunta de cómo los índices representativos o ídolos pueden considerarse otros sociales, repositorios de agencia y sensibilidad, parece llevarnos a mirar hacia la cuestión de las creencias y las prácticas ‘supuestamente irracionales'. Ciertamente, resulta 
Jesucristo, San Pedro y la Virgen, como individuos históricos, se diferencian de las imágenes que los representan, pero, a su vez tienen la convicción de que se manifiestan en ellas ${ }^{64}$.

Respecto al reparo de que un objeto inanimado es incapaz de manifestar una voluntad propia y hacer cosas - a diferencia de un sujeto humano-, la teoría de la agencia subraya que una "acción" no es lo mismo que un "hecho". Hay infinidad de comportamientos humanos que no proceden propiamente de acciones voluntarias, pero dan lugar a hechos y determinan nuestra existencia - por ejemplo, todo acto reflejo. En este sentido, el mantenerse inmóvil, como una imagen de yeso, también es una acción. ¿Puede ser que la persona sagrada del prototipo encarnada en el índice no quiera moverse, no quiera respirar, no quiera reproducir en la imagen una temperatura de $36,8^{\circ} \mathrm{C}$, pero que, a pesar de esas limitaciones, quiera actuar y manifestarse como imagen? ¿No será su inmovilidad también un acto reflejo? ¿No actuará sencillamente a otra "escala"?

Como subraya Gell (2016: 168), dichos atributos (temperatura corporal, desplazamiento, e incluso facultades como el hablar o el sentir) los poseen los humanos en calidad de "cosas", no como personas agentes. Solo cuando se ejercen ciertas facultades - cuando se habla y se siente de una determinada manera, única e irrepetible- estamos ante una persona humana. De manera análoga, podríamos afirmar que, en el caso de la imagen en el contexto de las fiestas que hemos estudiado, ciertas facultades

irracional o, al menos, extraño hablarle a una simple escultura, ofrecerle comida, vestirla y bañarla en vez de interactuar de esta manera con otro ser humano. Y así es; quienes siguen tales prácticas son tan conscientes de la «rareza» de su conducta como nosotros, pero ellos piensan, a diferencia de nosotros, que adorar al ídolo es eficaz religiosamente y surte efectos beneficiosos para ellos y los amos a los que sirven como sacerdotes. Estos sí pueden distinguir entre los leños, las piedras y las personas; solo ocurre que, en ciertos contextos, los leños y piedras poseen propiedades ocultas e inusuales que ignoran los legos y en los que no creen, equivocadamente, los instruidos, pero escépticos." (Gell, 2016: 166)

64 "Nosotros, cuando llegamos acá a La Tirana, un día antes se prepara a la Virgen. Se lava, se limpia... A mí, antes de que me entregaran a la Virgen, la Mary siempre me decía que ella era como muy especial. Entonces, muchas veces, no sé, decía «ay, si es de yeso, como va a ser especial», es como llegar y poner algo no más poh. En el momento en que uno viste a la Virgen, es como distinto. Porque, por ejemplo, ella hay cosas que no le gustan y que no se pone y no se pone no más. De ropa o la peluca... No quiere, no quiere y no quiere... Entonces, cuando Mario y Sonia se hicieron cargo, yo le dije lo mismo que Mary me dijo a mí. Que la Virgen tenía un proceso: todo es delicado, como que uno tiene que ir conversando con ella, para que ella se vaya adecuando a uno." (T3). En Tirana tuvimos la oportunidad de registrar este momento. En Caguach, en cambio, la vestida del Nazareno se da durante la madrugada en la sacristía, y está estrictamente prohibida la presencia de personas ajenas a dicho ritual (el Patrón y los promesantes); incluso, los asistentes no pueden grabar ni sacar fotografías. 
humanas del prototipo "universal", se ejecutan en los índices "particulares" al relacionarse con los destinatarios, constituyéndose el prototipo en persona a través de la imagen. En una palabra: encarnándose.

Las imágenes - y las cosas, en general- tienen un poder propio que emana de su misma constitución material. Esta es una afirmación que puede ser validada desde diferentes enfoques teóricos: desde la estética, la semiótica o las ciencias sociales, e incluso desde las ciencias naturales. La teoría de la agencia pone de relieve, sin embargo, que dicho poder no se deposita en la imagen de manera pasiva y discrecional, como en un recipiente, sino que la imagen misma, en su relación con las personas humanas, va ejerciendo su propia alteridad personal. Dicho de otro modo, que el misterio de la animación de las imágenes es un camino de dos sentidos, que no se detiene ni en el prototipo y ni en el índice, ni en lo universal ni en lo particular (Gell, 2016: 194).

A la luz de los planteamientos de la teoría de la agencia, parece bastante razonable postular que las imágenes son índices de la agencia social y que "Sean cuales sean los atributos que hacen religiosamente eficaces a los idolos como locus para encuentros directos con las deidades, no se pueden confirmar ni refutar con pruebas físicas como la presencia de pulso, respiración, ingestión y eliminación, la habilidad para moverse o hablar, un rechazo natural por los ratones, etc." (Gell, 2016: 169). Se puede postular de manera general que hay muchos casos en que las imágenes "actúan" como personas, pero no se puede responder de manera universal el por qué lo hacen. En este punto, como destaca Gell, son los actores mismos de dichas prácticas, sus mitos y sus intuiciones teológicas, los que pueden decir algo más de este misterio.

En su trabajo, Gell (2016: 159-164) analiza algunos casos, como el de la veneración de imágenes en el hinduismo, en las cuales se manifiesta el Darschan o la mirada de los dioses (2016: 159-164); o casos de imágenes a las que los sacerdotes-artistas les confieren una sustancia vital (2016: 189199). Los actores de las tres fiestas que hemos presentado hablan de la imagen como de una persona que es "como" ellos ${ }^{65}$, pero que tiene poder y en la que se manifiesta una "energía" que es más poderosa que los dogmas religiosos, pues incide de manera concreta y directa en la vida de las personas, haciéndolas participar en la vida divina ${ }^{66}$. La imagen, en defini-

65 "San Pedro como que... más que una imagen para nosotros, es un miembro de nuestra familia. Un hermano, un tío, un abuelo, una cosa así.” (SP 1).

66 "El Nazareno, al momento de que tú te creces en la isla, el Nazareno es parte de la vida cotidiana, es parte de tus proyectos, siempre está presente, más que la imagen, es energía acumulada por 200 años de tradición, más de 200 años... O sea, para nosotros, 
tiva, es una persona que se relaciona con los destinatarios a través de interacciones concretas y que, en el contexto de la fiesta religiosa, asume una función propiamente sacramental, en el sentido de constituirse en una epifanía del prototipo sagrado en el índice:

Para nosotros, la imagen no es imagen, para nosotros, la imagen es persona, por eso se viste, y se viste buscando lo sagrado. Y como su ropa es sagrada, ahí está la unión con nosotros, porque nosotros también nos vestimos para tener un momento sagrado. $Y$ ahí se produce lo que llamamos nosotros "encuentro". Encuentro de la mamita Virgen con un pueblo que canta, que sufre, que llora, que ríe, y que busca a través de ella poder tener la gracia de encontrarse con Dios. (T1)

\section{CONCLUSIONES}

No bay templo fisico de esta fe. El templo de esta fe popular, el templo es María. (T1).

Hemos planteado la fiesta religiosa como una categoría más consistente que la de "religión popular" para comprender ciertas prácticas y objetos que caracterizan la experiencia de fe de los pueblos latinoamericanos, bajo el supuesto de que este último es un término negativo y ambiguo que se suele definir por contraposición a las expresiones institucionales del catolicismo. La categoría de "fiesta religiosa", por el contrario, no se agota en esta contraposición, como tampoco cancela su relación con la institución eclesiástica. La ventaja que presenta la fiesta religiosa respecto al término genérico de "religión popular", es que se corresponde con una realidad empírica concreta, cuyos objetos y prácticas constituyen la pervivencia de un sistema cultural que se origina en el periodo de la Colonia.

Así, en cuanto sistema cultural, la fiesta religiosa presenta una dimensión política, económica, y social, encarnada en las sociedades de baile, el sindicato o el cabildo, con cierto grado de autonomía e institucionalidad y que busca legitimarse ante otras instancias institucionales. La fiesta religiosa, en definitiva, muestra un equilibrio dinámico de todas aquellas tensiones que constituyen el fenómeno de la religión popular en nuestros días y visibiliza de manera paradigmática su modo de ser festivo e icónico.

Por otro lado, hemos puesto de relieve el principio matérico-sensorial de la fiesta religiosa —su "lógica estética", podríamos decir- que se condensa en la relación personal que establecen los participantes de las fiestas

los indígenas, fue el comienzo... La puerta hacia una religión. Si bien nos cambiamos, de a poco se fue introduciendo la religión, nunca logró alcanzar la potencia que alcanza imagen, porque la imagen es más que la religión en sí.” (C2). 
con la imagen que las ocasiona. Como hemos visto, el prototipo no está en el índice de manera metafórica sino como una presencia. Ciertamente, esta dimensión sacramental - esta representación personal- que se atribuye a la imagen y a tantos otros objetos característicos de la religión popular - animitas, reliquias, estampitas - puede ser problemática para ciertas concepciones de la obra de arte. También lo es para ciertas teologías. Con todo, la estética y la teología no han podido evitar que estas prácticas supuestamente "irracionales" o "paganas" pervivieran hasta nuestros días, suscitando creciente interés en los especialistas, entre ellos los representantes de la denominada new material culture o la denominada Teología del Pueblo, que ha marcado el enfoque pastoral del Papa Francisco.

Ahora bien, según la información recopilada en nuestro estudio, la "representación personal" que opera en la imagen no se puede explicar en términos de idolatría (identificación entre índice y prototipo) como tampoco simplemente en términos semióticos (diferenciación categórica entre significante y significado). Su complejidad reside, justamente, en la aparente paradoja de que, por una parte, es el prototipo (la Virgen María, San Pedro, Jesús de Nazaret) "quien" hace actuar a la imagen de una determinada manera, pero, por otra, es el indice (ese pedazo de yeso con peluca) "quien" lleva a cabo estas acciones por su propia cuenta, pues suceden en un presente donde dichas personas históricas ya no están pero, no obstante, se muestran como una reacción voluntaria de estas personas a un estímulo puntual en el aquí y ahora de los destinatarios.

Esta suerte de duplicación de la persona en prototipo e imagen y la posibilidad de que en la imagen material se haga presente aquella persona que "ya no está", es abordada por la teoría de la agencia y también por otras teorías estéticas ${ }^{67}$. La legitimidad de esta forma de entender la representación -que, repetimos, no es ni idolátrica ni meramente semiótica-, sin embargo, no ha sido problematizada teológicamente respecto al caso de la denominada "religión popular". La siguiente fase de nuestra investigación abordará justamente esta cuestión, a partir de la elaboración de un aparato conceptual estético-teológico. Así, una vez que hemos asegurado una consistente base empírica para nuestra reflexión teórica, los pasos a seguir son: a) establecer la validez epistemológica de la lógica estética de la

\footnotetext{
67 'Por lo pronto, me interesa la idea de Hirn de que si el 'aspecto' de las cosas es parte material de ellas, entonces la influencia que se ejerce sobre alguien al manipular su imagen es comparable y hasta idéntica a la que se actúa al afectar una parte física de él, sobre todo, si consideramos que las personas pueden estar 'distribuidas'; es decir, no todas sus «partes» están unidas físicamente, sino que se esparcen en el ambiente, como las «túnicas añosas de las cigarras» que se mencionan en los memorables versos de Lucrecio, que son tanto imágenes como partes de aquellos seres vivos." (Gell, 2016: 147-148). Véase también Gadamer, 1991: 182-222, en particular el concepto de "valencia óntica" de la imagen.
} 
fiesta religiosa y b) definir de qué manera y en qué sentido la fiesta religiosa se constituye en lugar teológico.

¿Estas imágenes sin mediación que se activan sacramentalmente durante la fiesta, estos objetos y prácticas que articulan la fe de los pueblos latinoamericanos, son instancias de revelación o apenas intuiciones de una fe que debe ser filtrada por el cedazo de la teología y el magisterio? ¿En qué sentido hay que interpretar el estatuto de "lugar teológico" que se confiere a estas prácticas en Evangelii gaudium?

\section{REFERENCIAS}

AA.VV. (1996). Editorial. Journal of Material Culture, 1(1), 5-14.

Aguirre, F. (2018a). Fundamentos estético-teológicos de la piedad popular. Proyecto Fondecyt Iniciación $n^{\circ} 11170285$. Investigador responsable: Federico Aguirre. Teologia y Vida, 59(1), 155-160.

Aguirre, F. (2018b). Arte y Teología. El renacimiento de la pintura de íconos en Grecia moderna. Santiago de Chile: Ed. UC.

Bajtin, M. (2003). La cultura popular en la Edad Media y el Renacimiento. El contexto de Francoise Rabelais. Madrid: Alianza.

Bentué, A. (2015). La opción creyente. Santiago de Chile: San Pablo.

Taylor, S. \& Bogdan, R. (1987). Introducción a los Métodos Cualitativos de Investigación. La búsqueda de significados. Barcelona: Paidós Ibérica.

Cárdenas, R. \& Trujillo, C. (1986). Caguach, isla de la devoción. Religiosidad popular de Chiloé. Santiago de Chile: LAR.

CELAM (2007). Quinta Conferencia General del Episcopado Latinoamericano - Aparecida. Bogotá: San Pablo

CELAM (1979). Tercera Conferencia General del Episcopado Latinoamericano - Puebla. Bogotá: CELAM

CELAM (1968). Segunda Conferencia General del Episcopado Latinoamericano - Medellin. Bogotá: San Pablo.

Congregación para el Culto Divino y la Disciplina de los Sacramentos (2012). Directorio sobre la piedad popular y la liturgia. Principios y orientaciones. Madrid: BAC.

Cruz de Amenábar, I. (1995). La fiesta: metamorfosis de lo cotidiano. Santiago de Chile: Ediciones UC.

Dawson, M. T. (2001). The concept of popular religion: A literature review. Journal of Iberian and Latin American Research, 7(1), 105-132.

De la Maza, M. (2005) "Fundamentos de la filosofía hermenéutica: Heidegger y Gadamer". Teología y vida, 46, 122-138.

Delgado, M. (1993). La "religiosidad popular". En torno a un falso problema. Gazeta de Antropología, (10), Artículo 8. https://digibug.ugr.es/bitstream/handle/10481/13637/G10_08Manuel_Delgado.pdf?sequence $=10$ \&is Allowed $=\mathrm{y}$

Domańska, E. (2006). The return to things. Archaeologia Polona, 44, 171-185. 
Francisco (2015). Exhortación Apostólica Evangelii gaudium. Roma: Tipografía Vaticana.

García, R. (2003). Espacio sagrado y Religiosidad Popular: perspectivas veterotestamentarias. Teología y vida, 44, 310-331

Gadamer, H.-G. (1991). Verdad y método I. Sígueme: Salamanca.

Gell, A. (2016). Arte y agencia. Buenos Aires: SB.

Gera, L. (1976). Pueblo, religión del pueblo e Iglesia. Teología, (27-28), 99-123.

Gianinni, H. (2004). La reflexión cotidiana. Hacia una arqueología de la experiencia. Santiago de Chile: Ed. Universitaria.

González, M. (Ed.) (2017). La fiesta en Colombia. Bogotá: Credencial Historia.

Heidegger, M. (1992). Arte y poesía. Buenos Aires: FCE.

Heidegger, M. (1998). Ser y tiempo, Santiago de Chile: Ed. Universitaria.

Isambert, F.-A. (1982). Le sens du sacré. Fête et religion populaire. Ed. du Minuit: Paris.

Johansson, C. (1990). Religiosidad popular entre Medellin y Puebla: antecedentes y desarrollo. Santiago de Chile: Anales de la Facultad de Teología UC.

Martínez, S. (2012). La antropología, el arte y la vida de las cosas. Una aproximación desde Art and Agency de Alfred Gell. Revista de Antropología Iberoamericana, 7(2), 171-196.

Mercado, C. (ed.) (2006). Fiestas tradicionales populares de Chile. Quito: IPANC.

Meyer, W. (1952). Voces indígenas del lenguaje popular chileno. Padre Las Casas: Imp. San Francisco.

Morandé, P. (2010). Ritual y palabra. Santiago de Chile: IES.

Morgan, D. (ed.) (2010). Religion and Material Culture: The Matter of Belief. London and New York: Routledge.

Moulián, R. (2011). Gozos de santo. Fiesta, ecumenismo, heteroglosia. Valdivia: Kultrún.

Núñez, L. (2015). La Tirana: desde sus orígenes hasta la actualidad. Antofagasta: Eds. del Desierto.

Parker, C. (1993). Otra lógica en América Latina. Religión popular y modernización capitalista. Santiago de Chile: FCE.

Peirce, C. S. (1986). La ciencia de la semiótica. Buenos Aires: Nueva Visión.

Peña, N. (2015). Bailes religiosos de Arica. Arica: Procultura.

Pieper, J. (2006). Una teoría de la fiesta. Madrid: Rialp.

Plath, O. (1966). Folklore religioso chileno. Santiago de Chile: PlaTur.

Plath, O. (2012). L'animita. Hagiografía folclórica. Santiago de Chile: FCE.

Scanonne, J. C. (2014). El papa Francisco y la teología del pueblo. Razón y fe, 271(1395), 31-50.

Schultz, U. (1994). La fiesta: de las Saturnales a Woodstock. Madrid: Alianza

Uribe, J. (1976). Fiesta de La Tirana de Tarapacá. Valparaíso: Eds. Universitarias.

Van Kessel, J. (1987). Lucero brillante: mística popular y movimiento social. Iquique: Universidad Libre de Amsterdam.

Wittgenstein, L. (2016). Observaciones sobre La rama dorada de Frazer. Santiago de Chile: Ed. Tácitas. 